\title{
THE FAUNA ASSOCIATED WITH OUTER SHELF AND UPPER SLOPE SPONGES (PORIFERA, DEMOSPONGIAE) AT THE FAROE ISLANDS, NORTHEASTERN ATLANTIC
}

\author{
AnNe B. KLITGAARD
}

\section{SARSIA}

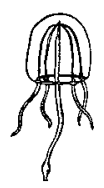

Klitgaard, Anne B. 199507 26. The fauna associated with outer shelf and upper slope sponges (Porifera, Demospongiae) at the Faroe Islands, northeastern Atlantic, -Sarsia 80:1-22. Bergen. ISSN 0036-4827.

Eleven sublittoral sponges, Geodia barretti, G. macandrewii, Geodia sp., Isops phlegraei, Stryphnus ponderosus, Thenea levis, $T$. valdiviae, Phakellia robusta, $P$. rugosa, $P$. ventilabrum and Tragosia infundibuliformis, all of which are widely distributed in the North Atlantic, were examined for associated fauna. At least $242 \mathrm{epi}$ - and infauna species were found, of which 115 are reported as sponge associates for the first time in the North Atlantic. Sixty species, 19 genera and 1 family are recorded for the first time from the Faroes. Two hundred and twenty-five taxa were found as epifauna on the sponges, three taxa occurred as infauna and 14 taxa both as epi- and infauna.

The morphology of the sponges influences the occurrence and composition of the represented fauna. Thus, the largest number of taxa were present on sponges having a spicule 'fur'. A number of species showed preference for the oscular cavities of $S$. ponderosus and the incurrent furrow of $T$. levis and $T$. valdiviae. Only one sponge predator, Hanleya nagelfar, was found. The majority of the associated fauna uses the sponges as a substratum. Three categories of direct effect of interactions between the sponges and the associated fauna are proposed. The results of the present investigation show that demosponges constitute a substratum for a large number of benthic taxa on the outer shelf and upper slope in the northeastern Atlantic, and that the scarcity of earlier reports is a result of insufficient investigation. It is suggested that the fauna associated with sponges in temperate to cold waters is facultative, representing the fauna of the local geographical area. This is in contrast to the large number of apparently obligate associates of Porifera in warm tropical waters.

Anne B. Klitgaard, Zoological Museum, University of Copenhagen, Universitetsparken 15, DK-2100 Copenhagen $\emptyset$., Denmark.

\section{INTRODUCTION}

Demosponges have been shown to be inhabited by a wide diversity of invertebrates. The relevant literature has been reviewed for a number of faunal groups by Arndt (1933), Arndt \& Pax (1936), Arndt \& Viets (1939) and LaUCKNer (1980). PeArse (1932) referred to demosponges as 'veritable living hotels', and according to BACESCU (1971) sponges constitute, next to tropical coral reefs, one of the richest and most interesting biotopes.

When reviewing the literature concerning fauna associated with demosponges in the North Atlantic (approximately north of $20^{\circ} \mathrm{N}$ ) some general characteristics appear. The majority of the investigations originate from shallow water in warmer areas such as the Mediterranean (SANTUCCI 1922; TUZET \& Paris 1964; VIDAL 1967; Pansini 1970; Rützler 1976; Koukouras \& al. 1985, 1992; Voultsiadou-Koukoura \& al. 1987), the Caribbean (Westinga \& HoetJes 1981; Villamizar \& Laughlin 1991) and the Gulf of Mexico (Pearse 1932).

\section{Contribution from the BIOFAR project.}

The investigations have often focused on the association between a single faunal group or species and sponges (Allman 1874; Fage 1928; Rees 1939; BoulLLON 1965, 1971; STOCK 1967a, b, c; BACESCU 1968, 1980; Rützler 1968; Calder 1970; Dauer 1973; Heard \& Perlmutter 1977; Brattegard 1980; Biernbaum 1981; Riser 1982; Uebelacker 1982; PaWlik 1983; Zullo \& Standing 1983; Oshel \& STeele 1985; Dounas \& KouKOURAS 1986; ERdMAN \& BlaKe 1987; Williams 1987; SCOTT \& al. 1988; Lugli \& PalazzI 1991; DuFfy 1992; URIZ \& al. 1992). Only a small number of reports exist from the eastern Atlantic boreal region (FRITH 1976, 1977; Forester 1979; Peattie \& Hoare 1981; Bongers 1983; Costello \& Myers 1987), and even fewer on associations at greater depths (> $100 \mathrm{~m})\left(\mathrm{V}_{\mathrm{ADER}} 1984 \mathrm{a}, \mathrm{b}\right.$; CedHagen 1994). In addition, some scattered information exists in the form of comments in connection with descriptions of species in expedition reports (LUNDBECK 1902, 1905, 1910). This scarcity of literature suggests either that associations involving sublittoral demosponges are rare in the North Atlantic, or insufficient investigations. 


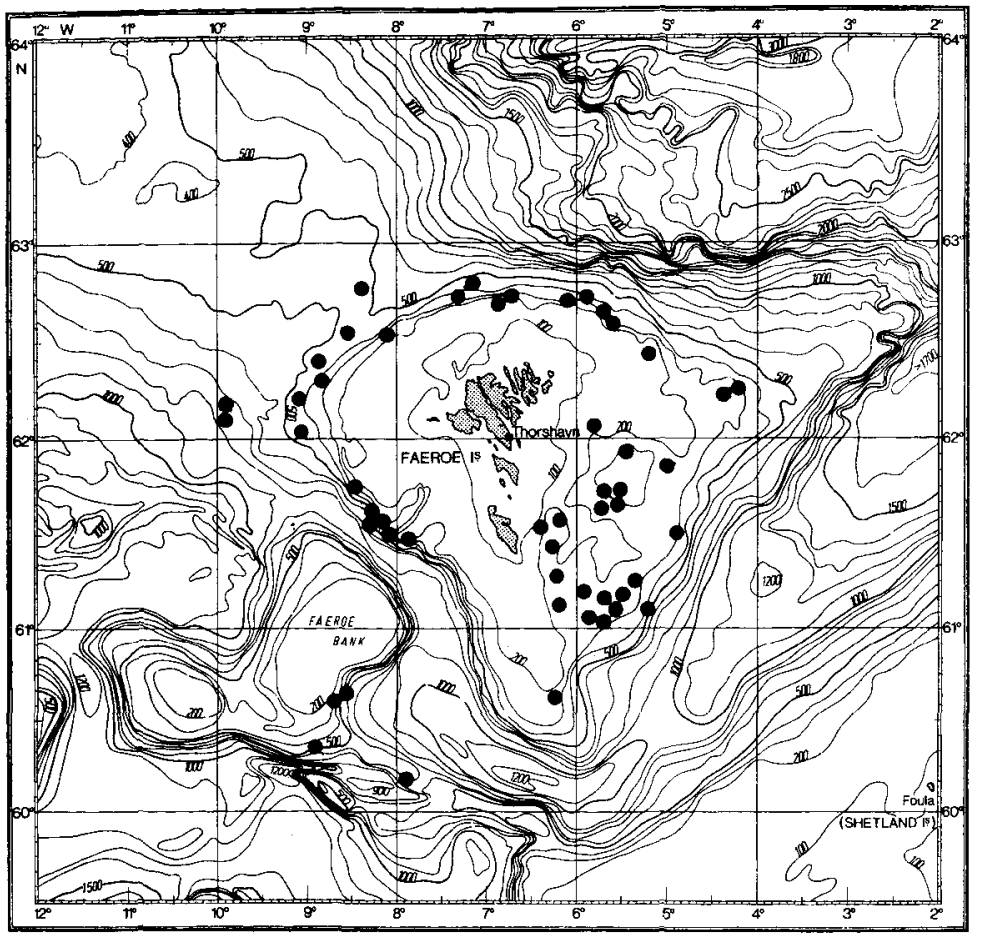

Fig. 1. BIOFAR stations (filled circles) at which sponges examined for associated fauna were collected. Stations placed very close to each other are only indicated with one mark.
The aims of the present investigation are to examine the existence of associations with demosponges on the outer shelf and upper slope in the northeastern Atlantic, and to examine the importance of sponge morphology for the composition of a possible associated fauna.

However, because of the uncertainties that inevitably are connected with qualitative sampling methods, as well as the limited knowledge of the biology of the single species, the existence of a closer association between the represented fauna and the sponges can only rarely be demonstrated.

Thus, if not otherwise specified the term 'associate' as used in this paper exclusively refers to any species which was found on or in the sponges. Two species, Gnathia abyssorum (Isopoda) and Hanleya nagelfar (Polyplacophora), have previously been reported associated with sponges at the Faroe Islands (KLITGAARD 1991; WARÉN \& KlITGAARD 1991).

Table 1. Systematic position of the 11 examined sponge species, and the number of specimens of each species examined for in-and epifauna in the laboratory and for associated macrofauna in the field. For list of BIOFAR stations at which specimens of each species were collected, see Appendix 2.

\begin{tabular}{|c|c|c|c|c|}
\hline \multirow[b]{2}{*}{ Order } & \multirow[b]{2}{*}{ Family } & \multirow[b]{2}{*}{ Species } & \multicolumn{2}{|c|}{ Number of specimens } \\
\hline & & & Laboratory & Fielú \\
\hline Choristida & Geodiidae & Geodia barretti BowERBANK, 1858 & 28 & $123-133$ \\
\hline- & - & G. macandrewii BowerBANK, 1858 & 27 & 15 \\
\hline- & - & Geodia sp. & 32 & 68 \\
\hline- & - & Isops phlegraei SOLLAS, 1880 & 31 & 73 \\
\hline- & Stellettidae & Stryphnus ponderosus (BOWERBANK, 1866) & 50 & $>483$ \\
\hline- & Theneidae & Thenea levis LENDENFELD, 1906 & 36 & - \\
\hline- & - & T. valdiviae LENDENFELD, 1906 & 44 & - \\
\hline Axinellida & Axinellidae & Phakellia robusta BowERBANK, 1866 & 59 & - \\
\hline- & - & P. rugosa (Bowerbank, 1866) & 25 & - \\
\hline- & - & P. ventilabrum (JOHNSTON, 1842) & 37 & - \\
\hline- & - & Tragosia infundibuliformis (FLEMING, 1866) & 42 & - \\
\hline
\end{tabular}




\section{MATERIAL AND METHODS}

\section{The sponges}

Eleven species, all widely distributed in the North Atlantic, were examined. They belong to the Demospongiae and represent two orders and four families (Table 1). The species were selected according to the following main criteria:

1. Common at the Faroe Islands. 2. Achieve a large size. 3. Of different morphologies.

The choristid species are characterized by a dominant mineral skeleton of silica spicules giving these sponges a very solid texture, while the axinellid species have a compound spicule and fibre skeleton resulting in a more elastic texture.

Following the family classification (BERGQUIST 1978) the eleven species can be divided into four morphological groups:

Geodi id a e. Large, massive sponges (up to $72 \mathrm{~cm}$ in maximum dimension), characterized by a cortex of globular microscleres (sterrasters). A 'fur' of vertically oriented spicules can be found on the surface of Geodia macandrewii and Isops phlegraei. G. barretti has the osculae assembled in depressions covered with a sieve, the number and depth of which vary.

S tell e tt i d a e. Large, massive sponges (maximum dimension of Stryphnus ponderosus $45 \mathrm{~cm}$ ), always covered by a $3-5 \mathrm{~mm}$ thick 'fur' of spicules. The osculae are assembled in one or more of up to $20 \mathrm{~cm}$ deep cavities.

Th e n e i a e. Smaller sponges (maximum dimension $16 \mathrm{~cm}$ ), always covered by a thick 'fur' of spicules. Thenea levis is elongate with the in- and excurrent furrows on the opposite long sides. T. valdiviae is sphere-shaped or lump-formed with an equatorial incurrent furrow, and one or more osculae on top of the body.

A $x$ inellidae. Foliaceous or funnel-shaped (Phakellia robusta, $P$. ventilabrum and Tragosia infundibuliformis) or ramified sponges $(P$. rugosa), (maximum height $23 \mathrm{~cm}$ ). A specimen of $P$, robusta and $P$. ventilabrum consists of one or more 'fans', and the occurrence of folds or other irregularities on the fan vary. The number of branches of $P$. rugosa also vary.

\section{Field sampling}

Material was collected during BIOFAR cruises in May/June (1988, '89), July (1987, '88, '89), September/October (1989, '90) and November (1988, '89). Sponges were selected from 73 stations at depths hetween 157 and $780 \mathrm{~m}$. located around the Faroes (Fig. 1). Samples were collected with triangular dredge (43 stns), shell-dredge ( 8 stns), detritus sledge ( 9 stns). Alfredo trawl (11 stns) and Rothlisberg \& Pearcy epibenthic sledge (2 stns).

All sponges were sorted as soon as the sample came onboard. Selected specimens were, depending on their size, either packed separately or together with other specimens of the same species, and fixed in $4 \%$ borax-buffered formaldehyde. At stations where the number of specimens of Stryphnus ponderosus and representatives of the Geodiidae was very large (more than c. 20 specimens), the major part of the sponges was examined onboard and a representative selection of the associated macrofauna was kept.

\section{Laboratory procedure}

The sponges were rinsed in freshwater in an overflow vessel with the outflow water sieved through a $0.5 \mathrm{~mm}$ mesh, and transferred to $80 \%$ ethanol.

The examination of the sponges for epifauna included cutting open the oscular cavities of Stryphnus ponderosus and examining the in- and excurrent furrows and osculae of Thenea levis and T. valdiviae. Depending on the morphology of the sponges, they were subsequently either cut into $1 \mathrm{~cm}^{3}$ pieces or examined directly under a stereomicroscope for in- and smaller epifauna. Specimens of $T$. levis and $T$, valdiviae were always examined whole. Depending on the size of the other species, either the whole specimen or half of it (if very large, only $1 / 3$ or $1 / 4$ ), was examined. To make sure that all faunal elements were removed from the thick 'fur' of spicules on S. ponderosus, T. levis and T. valdiviae and some Geodia macandrewii, the dissected pieces of these species were sieved in, respectively, a $4 \mathrm{~mm}$ and a $0.5 \mathrm{~mm}$ sieve, and the $0.5 \mathrm{~mm}$ fraction was examined under a stereomicroscope. Additional fauna was searched for in the alcohol that the sponges had been stored in after sieving through a $0.5 \mathrm{~mm}$ sieve.

The associated fauna was classified as epi- or infauna, depending on whether the fauna was found on the surface of the sponges. including in the spicule 'fur', or inside the canals or the tissues. The term epifauna comprises here both errant and sessile species.

The fauna found was as far as possible identified to species level. Sometimes this was not possible owing to the lack of specialists or because the material was too damaged. Thus, the term taxon as used in this paper may refer to different levels of identification (species, genus, family etc.).

\section{Underwater photographs}

Eleven hundred underwater photographs were taken during a BIOFAR cruise in May 1990 at depths between 60 and $1050 \mathrm{~m}$ (J. Gutt, Alfred-Wegener-Institut für Polar- und Meeresforschung, Bremerhaven). A number of these photographs have been used in this investigation to supply extra information about the presence of motile fauna on the sponges.

\section{RESULTS}

The sponges

A total of 411 sponge specimens were examined in the laboratory for in- and epifauna and, additionally, more than 760 specimens were examined for associated macrofauna in the field (Table 1).

Six of the 11 species (G. barretti, Geodia sp., $I$. phlegraei, S. ponderosus, $P$. robusta and $T$. infundibuliformis) are new to the Faroese area.

\section{The associated fauna}

At least 242 species were found associated with the 11 sponge species (Table 2). One hundred and fifteen species are for the first time reported associated with sponges in the North Atlantic. No less than 60 species, 19 genera and 1 family (Polycitoridae) are new records for the Faroe Islands area (Appendix 1). 
Table 2. Numbers of taxa of each major group associated with each of the 11 examined sponge species. The total number of associated taxa of each group found in all 11 sponge species is shown (Total) as well as the percentage of this number of the total number of associated taxa (242) found (\%). The bottom row gives the total number of taxa associated with each of the sponge species. The indicated numbers include all taxa found associated with the sponges examined in the laboratory as well as in the field. G. $b$. $=$ Geodia barretti, G.m. $=$ G. macandrewii, G.sp. = Geodia sp., I.p. $=$ Isops phlegraei, S.p. $=$ Stryphnus ponderosus, T.I. $=$ Thenea levis, T.v. $=$ T. valdiviae, P.ro. $=$ Phakellia robusta, Pru. $=$ P. rugosa, $P . v .=$ P. ventilabrum, T..$=$ Tragosia infundibuliformis.

\begin{tabular}{|c|c|c|c|c|c|c|c|c|c|c|c|c|c|}
\hline & G.b. & G.m. & G.sp. & I.p. & S.p. & T.l. & T.v. & P.ro. & Pru. & P.v. & T.i. & Total & $\%$ \\
\hline Protozoa & 2 & 5 & 2 & 10 & - & - & - & - & - & - & - & 12 & 5.0 \\
\hline Porifera & - & 1 & 1 & 1 & 2 & 1 & 1 & 1 & 1 & 1 & 1 & 2 & 0.8 \\
\hline Hydrozoa & 1 & 2 & 6 & 8 & 3 & 1 & 1 & 3 & 3 & 3 & 3 & 14 & 5.8 \\
\hline Anthozoa & 2 & - & - & 1 & 2 & - & - & - & - & - & - & 3 & 1.2 \\
\hline Nemertea & - & 1 & - & - & 1 & 1 & - & - & - & - & - & 1 & 0.4 \\
\hline Nematoda & - & 9 & - & 2 & 15 & 15 & 12 & 1 & 3 & 3 & - & 27 & 11.2 \\
\hline Polychaeta & 3 & 21 & 6 & 9 & 35 & 38 & 41 & 9 & 4 & 1 & 5 & 63 & 26.0 \\
\hline Oligochaeta & - & 1 & - & - & 1 & 3 & 1 & - & 1 & - & - & 3 & 1.2 \\
\hline Polyplacophora & - & 1 & 1 & 1 & 1 & 1 & - & - & - & - & - & 1 & 0.4 \\
\hline Gastropoda & - & - & - & - & 1 & - & - & - & - & - & - & 1 & 0.4 \\
\hline Bivalvia & - & 6 & 3 & 3 & 3 & 6 & 3 & 3 & 1 & - & - & 10 & 4.1 \\
\hline Arachnida & - & - & - & - & 1 & - & - & - & - & - & - & 1 & 0.4 \\
\hline Pycnogonida & - & - & - & - & 2 & 2 & 3 & 1 & 1 & - & - & 7 & 2.9 \\
\hline Cirripedia & - & - & 1 & 1 & 1 & - & - & - & - & 1 & - & 2 & 0.8 \\
\hline Tanaidacea & - & 1 & - & - & - & 1 & 1 & 1 & - & - & - & 1 & 0.4 \\
\hline Isopoda & - & 2 & - & - & 4 & 2 & 1 & 3 & - & - & 2 & 7 & 2.9 \\
\hline Amphipoda & - & 3 & - & - & 6 & 4 & 2 & - & 3 & 1 & - & 16 & 6.6 \\
\hline Decapoda & - & - & - & - & 2 & - & - & 2 & - & - & - & 4 & 1.7 \\
\hline Sipuncula & - & 1 & - & 2 & 3 & 4 & 3 & - & - & - & - & 5 & 2.1 \\
\hline Bryozoa & - & 3 & 3 & 11 & 19 & 15 & 13 & 13 & 5 & 7 & 2 & 31 & 12.8 \\
\hline Brachiopoda & - & 1 & - & 1 & 1 & 1 & 1 & 1 & - & - & - & 2 & 0.8 \\
\hline Ophiuroidea & 2 & 2 & 2 & 2 & 13 & 5 & 3 & 4 & 6 & 4 & 2 & 17 & 7.0 \\
\hline Pterobranchia & - & - & - & - & - & I & 1 & - & - & - & - & 1 & 0.4 \\
\hline Ascidiacea & - & 2 & - & 2 & 6 & 7 & 3 & - & - & 1 & - & 11 & 4.5 \\
\hline Total number & 10 & 62 & 25 & 54 & 122 & 108 & 90 & 42 & 28 & 22 & 15 & 242 & \\
\hline
\end{tabular}

The 242 species represent 14 phyla. The dominating groups are Polychaeta, Bryozoa and Nematoda with respectively $26,12.8$ and $11.2 \%$ of the total number of taxa (Table 2).

The distribution of the associated fauna on the sponges

Ophiopholis aculeata (Ophiuroidea) was present on 10 of the sponge species, 115 taxa were associated with only one sponge species, and the remaining taxa with 2-9 sponge species (Appendix 1). The total number of associated taxa vary between the sponge species (Table 2). Comparison of Tables 2 and 3 shows that the dominating faunal groups of each sponge species, in number of taxa, are also the most frequently found on a wider range of sponge species. It is also evident that groups that are represented only by few taxa in Table 2 , either because the groups have not been further identified, or because only few taxa were found, can be very frequently represented on the sponge species. As an example Porifera were frequently present on $I$. phlegraei, $S$. ponderosus, T. levis and T. valdiviae, and Hydrozoa were frequently found on the three last mentioned sponge species.
Table 4 shows that associated fauna was found on almost all specimens of $I$. phlegraei, S. ponderosus, $T$. levis, $T$. valdiviae and $P$. robusta and on 50-75\% of the specimens of the remaining sponge species, except for G. barretti. The number of taxa per sponge specimen was fairly even, except for G. macandrewii, P. robusta and $P$. rugosa, where a large number of associated taxa were present on a few specimens. Most specimens had none or only few associated taxa (Table 4).

The average number of associated taxa per sponge specimen was largest for $T$. levis, $T$. valdiviae and $S$. ponderosus in that order. The remaining sponge species all had low average numbers, about four or fewer taxa per specimen (Table 4). The discrepancy between the percentage occurrence of associated fauna and the average number of taxa present per sponge specimen is most pronounced in $P$. robusta and $T$. infundibuliformis. Only about 2-3 taxa and 1 taxon respectively were on average associated with a single sponge specimen, while associated fauna was found on more than three quarters of the examined specimens of both sponge species (Table 4). 
Table 3. Percentage occurrence of the fauna groups of each of the 11 sponge species. As only a representative selection of the associated macrofauna was preserved in the field on stations where the number of sponges was very large, the percentages are calculated on basis of the fauna present on sponges examined in detail in the laboratory. G.b. = Geodia barretti, G.m. $=$ G. macandrewii, G.sp. $=$ Geodia sp., I.p. = Isops phlegraei, S.p. = Stryphnus ponderosus, T.l. $=$ Thenea levis, $T . v .=T$. valdiviae, P.ro. $=$ Phakellia robusta, P.ru. $=P$. rugosa, $P$. . $=$ P. ventilabrum, $T . i$. $=$ Tragosia infundibuliformis

\begin{tabular}{lccccccccccc}
\hline & G.b. & G.m. & G.sp. & I.p. & S.p. & T.l. & T.v. & P.ro. & P.ru. & P.v. & Ti. \\
\hline Protozoa & 14.3 & 14.8 & 18.8 & 54.8 & - & - & - & - & - & - \\
Porifera & - & 11.1 & 6.3 & 58.1 & 50.0 & 44.4 & 31.8 & 6.8 & 4.0 & 2.7 & 9.5 \\
Hydrozoa & - & 11.1 & 25.0 & 41.9 & 84.0 & 72.2 & 50.0 & 33.9 & 36.0 & 27.0 & 38.1 \\
Anthozoa & - & - & - & 3.2 & 8.0 & - & - & - & - & - & - \\
Nemertea & - & 3.7 & - & - & 2.0 & 2.8 & - & - & - & - & - \\
Nematoda & - & 33.3 & - & 25.8 & 66.0 & 91.7 & 88.6 & 1.7 & 4.0 & 5.4 & - \\
Polychaeta & 10.7 & 37.0 & 12.5 & 38.7 & 74.0 & 88.9 & 90.9 & 91.5 & 16.0 & 2.7 & 11.9 \\
Oligochaeta & - & 3.7 & - & - & 2.0 & 19.4 & 6.8 & - & 4.0 & - & - \\
Polyplacophora & - & 11.1 & 12.5 & 6.5 & 10.0 & 2.8 & - & - & - & - & - \\
Gastropoda & - & - & - & - & 4.0 & - & - & - & - & - & - \\
Bivalvia & - & 22.2 & 6.3 & 12.9 & 10.0 & 47.2 & 40.9 & 1.7 & 4.0 & - & - \\
Arachnida & - & - & - & - & 2.0 & - & - & - & - & - & - \\
Pycnogonida & - & - & - & - & 4.0 & 8.3 & 9.1 & 3.4 & 4.0 & - & - \\
Cirripedia & - & - & - & 3.2 & - & - & - & - & - & 2.7 & - \\
Tanaidacea & - & 3.7 & - & - & - & 5.6 & 4.5 & 1.7 & - & - & - \\
Isopoda & - & 3.7 & - & - & 62.0 & 11.1 & 6.8 & 10.2 & - & - & 52.4 \\
Amphipoda & - & 7.4 & - & - & 10.0 & 8.3 & 4.5 & - & 16.0 & 2.7 & - \\
Decapoda & - & - & - & - & - & - & - & 3.4 & - & - & - \\
Sipuncula & - & 18.5 & - & 12.9 & 12.0 & 58.3 & 50.0 & - & - & - & - \\
Bryozoa & - & 18.5 & 9.4 & 38.7 & 56.0 & 83.3 & 56.8 & 30.5 & 16.0 & 21.6 & 7.1 \\
Brachiopoda & - & 3.7 & - & 6.5 & - & 2.8 & 4.5 & 3.4 & - & - & - \\
Ophiuroidea & 3.6 & 11.1 & 6.3 & 6.5 & 24.0 & 47.2 & 59.1 & 11.9 & 36.0 & 18.9 & 4.8 \\
Pterobranchia & - & - & - & - & - & 22.2 & 6.8 & - & - & - & - \\
Ascidiacea & - & 3.7 & - & 6.5 & 12.0 & 22.2 & 6.8 & - & - & 2.7 & - \\
\hline
\end{tabular}

Comments on single groups, including earlier records

Protozoa. Foraminiferans, especially species with calcareous shell attached to the cortex of the sponge, constitute a characteristic epifaunal group of the Geodiidae. Cibicides refulgens and Hyrrokkin sarcophaga were the most frequently found protozoans on all four geodiids.

Hyrrokkin sarcophaga is a parasite of Isops phlegraei and Dragmastra normani (Sollas, 1880) (Stellettidae) along Scandinavian coasts (CedHaGen 1994). Brown deposits as described by CedHagen (1994) were also observed in this investigation surrounding Hyrrokkin sarcophaga on all the Geodiidae. H. sarcophaga has recently been found living on the scleractinian coral Lophelia pertusa at the Faroe Islands (JENSEN \& FREDERIKSEN 1992).

Porifera. Sponges of different growth forms were often found on the surface of the examined sponge species, especially on the Choristida, with encrusting forms dominating. Very characteristic is Aplysilla sulphurea which has a conspicuous sulphur yellow pigmentation and often was found covering most of the surface of $S$. ponderosus. A. sulphurea has previously been recorded growing on three species of Demospongiae in the Adriatic Sea (Rútzler 1970).

Hydrozoa. The hydrozoans associated with Geodiidae and the athecate hydrozoans associated with Axinellidae were identified as far as possible. Sertularella gayi and Lafoea gracillima were the most commonly found hydrozoans on the geodiids (Appendix 1). S. gayi is, on account of its size of up to $25 \mathrm{~cm}$ (KRAMP 1935) and its frequent presence, a characteristic and conspicuous clcment of the cpifauna of the geodiids as well as of Stryphnus ponderosus.

The athecate hydrozoans associated with the axinellids all belong to the Tubulariidae. They all had the hydrorhiza embedded in the tissues of the sponges and the hydrocaulus extending in the surrounding water. They were so numerous on some axinellids that the sponge looked like a 'hedgehog'. The number of endodermal ridges in the hydrocaulus (c. 14 distally), indicates that some specimens might be Hybocodon prolifer, previously recorded growing in sponges at Reykjavik, Iceland and at Plymouth, England (Russell 1953; Petersen 1990). 
Table 4. Number of taxa per sponge specimen of the 11 sponge species examined of in- and epifauna in the laboratory. The three bottom rows indicate respectively: The number of sponge specimens examined in the laboratory with associated fauna (Number with fauna), the percentage occurrence of sponge specimens with associated fauna of the total number of specimens of each sponge species examined in the laboratory $(\%)$, and the average number of associated taxa per sponge specimen $\left(\mathrm{x}^{*}\right)$. G.b. $=$ Geodia barretti, G.m. $=$ G. macandrewii, G.sp. = Geodia sp., I.p. = Isops phlegraei, S.p. =Stryphnus ponderosus, T.l. $=$ Thenea levis, T.v. =T. valdiviae, P.ro. $=$ Phakellia robusta, P.ru.$=P$, rugosa, $P_{. v}=P$, ventilabrum, T. $i .=$ Tragosia infundibuliformis .

\begin{tabular}{|c|c|c|c|c|c|c|c|c|c|c|c|}
\hline \multicolumn{12}{|c|}{ Number of sponge specimens } \\
\hline Number of taxa & G.b. & G.m. & G.sp. & I.p. & S.p. & T.l. & T.v. & P.ro. & P.ru. & P.v. & T.i. \\
\hline 0 & 20 & 12 & 14 & 4 & - & 1 & 1 & 3 & 7 & 16 & 9 \\
\hline 1 & 8 & 3 & 7 & 3 & 4 & - & 1 & 29 & 11 & 12 & 17 \\
\hline 2 & - & 3 & 8 & 5 & 2 & 1 & - & 8 & 2 & 4 & 10 \\
\hline 3 & - & 1 & - & 1 & 2 & 3 & 7 & 4 & 2 & 3 & 5 \\
\hline 4 & - & - & 1 & 2 & 7 & 1 & 3 & 7 & - & 1 & 1 \\
\hline 5 & - & 3 & 1 & 6 & 5 & 4 & 1 & 2 & 2 & - & - \\
\hline 6 & - & 1 & - & 3 & 4 & 2 & 2 & 3 & - & - & - \\
\hline 7 & - & - & 1 & 3 & 6 & 1 & 1 & 1 & - & 1 & - \\
\hline 8 & - & - & - & 1 & 3 & - & 2 & 1 & - & - & - \\
\hline 9 & - & - & - & 1 & 3 & 2 & 2 & - & - & - & - \\
\hline 10 & - & 1 & - & - & 2 & - & 4 & - & 1 & - & - \\
\hline 11 & - & - & - & 1 & - & - & 4 & - & - & - & - \\
\hline 12 & - & - & - & - & 1 & 3 & 1 & - & - & - & - \\
\hline 13 & - & - & - & - & 1 & 2 & 3 & - & - & - & - \\
\hline 14 & - & - & - & - & 3 & 1 & 5 & - & - & - & - \\
\hline 15 & - & - & - & - & 1 & 1 & 1 & - & - & - & - \\
\hline 16 & - & - & - & 1 & 1 & 3 & 1 & - & - & - & - \\
\hline 17 & - & 1 & - & - & 2 & 3 & 1 & - & - & - & - \\
\hline 18 & - & - & - & - & 1 & 2 & 1 & - & - & - & - \\
\hline 19 & - & - & - & - & 1 & 1 & 1 & - & - & - & - \\
\hline 20 & - & - & - & - & - & - & - & - & - & - & - \\
\hline 21 & - & - & - & - & - & 2 & - & - & - & - & - \\
\hline 22 & - & - & - & - & - & - & - & 1 & - & - & - \\
\hline 23 & - & - & - & - & 1 & 1 & 2 & - & - & - & - \\
\hline 24 & - & - & - & - & - & - & - & - & - & - & - \\
\hline 25 & - & - & - & - & - & 1 & - & - & - & - & - \\
\hline 26 & - & 1 & - & - & - & 1 & - & - & - & - & - \\
\hline 27 & - & - & - & - & - & - & - & - & - & - & - \\
\hline 28 & - & - & - & - & - & - & - & - & - & - & - \\
\hline 29 & - & - & - & - & - & - & - & - & - & - & - \\
\hline 30 & - & 1 & - & - & - & - & - & - & - & - & - \\
\hline Number with fauna & 8 & 15 & 18 & 27 & 50 & 35 & 43 & 56 & 18 & 21 & 33 \\
\hline$\%$ & 28.6 & 55.6 & 56.3 & 87.1 & 100 & 97.2 & 97.7 & 94.9 & 72.0 & 56.8 & 78.6 \\
\hline$x^{*}$ & 0.3 & 4.3 & 1.2 & 4.4 & 7.9 & 12.0 & 9.7 & 2.5 & 1.6 & 1.1 & 1.3 \\
\hline
\end{tabular}

Anthozoa. Two species of Capnella were found on three sponge species (Appendix 1). Associations between sponges and octocorals have only rarely been reported from the North Atlantic (RÜTZLER 1976), while members of the subclass Zoantharia are commonly found as sponge associates (ARNDT \& PAX 1936; PeARSE 1947, 1950; WeSt 1976, 1979; LEWIS 1982; WeNDT \& al. 1985).

Nemertea. A few fragments were found in spicule 'fur' on three sponge species, but no attempt was made to reach a further identification (Appendix 1).
Nematoda. All nematodes were found in the 'fur' of the two Thenea species and $S$. ponderosus. An exception is one specimen of $S$. ponderosus, where nematodes were present in an internal cavity containing sediment and spicule accumulations. Nematodes were only found on geodiid specimens with a 'fur' of spicules. A few nematodes were found in the tissues of specimens of Phakellia and one on the surface of a P. robusta.

Nematodes were not included in 'The Zoology of the Faroes'. Seven of the genera found here have also been recorded with Lophelia pertusa at the Faroe Islands 
(JENSEN \& FREDERIKSEN 1992), giving a total of 14 genera and one species newly reported from this area. Enoplus communis has previously been found associated with littoral sponges at North Hayling, Hampshire, UK (FRITH 1976), and at the island of Texel, Netherlands (BONGERs 1983).

Polychaeta. Polychaetes were found either into spicule 'fur' or lying on the cortex of geodiid sponges. The tube-dwelling species were attached to the cortex. The largest number of polychaetes were found in the spicule 'fur' of S. ponderosus, T. levis and T. valdiviae. Exceptions are a few specimens of Eunicidae, Polynoidae and Nereis pelagica, which were found in the oscular cavities of $S$. ponderosus. In $P$. robusta all specimens of Syllidae and Lumbrineridae and two specimens of Polynoidae were found in the canals, the remaining polychaetes on the surface. One specimen of Exogone cf. naidina was present in the tissues of $P$. rugosa, while the remaining polychaetes were found on the surface. In $P$, ventilabrum polychaetes were only found on the surface, while in $T$. infundibuliformis all polychaetes were found inside the canals.

It is notable that the large percentage occurrence of polychaetes of $P$. robusta (Table 3 ) is mainly a result of occurrence of one species, Haplosyllis spongicola, present in $91.5 \%$ of the specimens. No other polychaete taxon is so frequently represented on the sponges. Ten of the listed polychaetes have previously been reported associated with sponges in the North Atlantic (Appendix 1) (Fauvel 1923; Vidal 1967; Bacescu 1971; Dauer 1973; Rullier 1974; Frith 1976; Uebelacker 1978; Fauchald \& Jumars 1979; Peattie \& HoAre 1981; Alós \& al. 1982; KouKoUras \& al. 1985; WeNDT \& al. 1985; Helgason \& al. 1990).

Olig ochaeta. Bathydrilus rarisetis was the most common species. The oligochaetes were found in spicule 'fur' on the choristids, and on the surface of $P$. rugosa.

Poly placoph ora. Hanleya nagelfar with a body length up to $70 \mathrm{~mm}$ is a very conspicuous epifaunal element of the choristids. Sometimes the chitons were found in excavated pits that could be so deep that the animals were almost hidden. Some specimens were found in the oscular cavity of $S$. ponderosus. The Faroese material has been included in a previous investigation on the biology of $H$. nagelfar (WARÉN \& KLITGAARD 1991).

Gastropoda. Only three specimens of Margarites sp. were found in the 'fur' on two $S$. ponderosus (Appendix 1). The specimens were in a very poor condition and could not be identified further than genus level.
Bivalvia. Modiolus phaseolinus and Hiatella arctica were the most common bivalves (Appendix 1). They were found in spicule 'fur' of G. macandrewii, attached to the cortex of Geodia sp., and partly attached to the cortex (all Heteranomia squamula and one specimen of Hiatella arctica) and partly sitting in the spicule 'fur' (one specimen of $H$. arctica and one $M$. phaseolinus) of I. phlegraei. On S. ponderosus all bivalves were found in the spicule 'fur'. One specimen of $M$. phaseolinus was attached to the sieve of the incurrent furrow of $T$. levis. Three specimens were sitting in the fringe of spicules on the upper rim of the incurrent furrow. Similarly, 13 specimens of $M$. phaseolinus and one specimen of $H$. arctica were attached to the upper rim of the incurrent furrow of $T$. valdiviae. The remaining bivalves of $T$. levis and $T$. valdiviae were all found in the spicule 'fur'. The bivalves associated with $P$. robusta were all found between small folds on a single specimen. One specimen of Dacrydium ockelmanni was sitting in the rim of a $P$. rugosa and was overgrown by the sponge. Only $H$. arctica has previously been reported associated with sponges, respectively in the Adriatic Sea (SANTUCCI 1922) and in the North Aegean Sea (Koukouras \& al. 1985).

Acariformes. One specimen of the Halacaridae was found in the 'fur' of a S. ponderosus (Appendix 1).

Py c nog on id a. A juvenile Nymphon sp. was deeply buried in the 'fur' of a T. valdiviae. An adult male of $N$. grossipes was found in an oscular cavity of a $S$. ponderosus. One adult male of $N$. leptocheles was sitting on the surface of a $P$. robusta, and one adult female was found between small folds on another specimen of this sponge species. One specimen of $N$. cf. micronyx was found in the 'fur' of a $T$, valdiviae. One ovigerous male of $N$. spinosissimum was attached by its claws to the surface of a $P$. rugosa. Two males (one larvigerous and one ovigerous), three adult females (one oviferous) and one juvenile of Callipallene producta were found in the 'fur' of $S$. ponderosus, T. levis and T. valdiviae. One adult female of Pseudopallene malleolata was attached by its claws to the surface of a T. levis.

Crustacea. The specimens of Apseudes spinosus were found in spicule 'fur' on G. macandrewii, T. levis and $T$. valdiviae and on the surface of a P. robusta.

Gnathia abyssorum was the most abundant isopod. It was most frequently found in the 'fur' of $S$. ponderosus and in the canals of Tragosia infundibuliformis. Adult males, females and juveniles were all found. A proposal to a life cycle of Gnathia abyssorum has been published (KlitgaARd 1991). Aega ventrosa was exclusively present in the oscular cavities of $S$. ponderosus. Both 
adult males, adult females, some with eggs or juveniles in the marsupium, and immatures were found. Most of the remaining isopods were found in the spicule 'fur' on Geodia macandrewii, S. ponderosus, Thenea levis, and $T$. valdiviae or on the surface or between folds in Phakellia robusta. The seven specimens of Nannoniscus oblongus were found in the spicule 'fur' of a $G$. macandrewii, forming a kind of 'harem' as they comprised 6 females ( 5 with eggs in the marsupium, and 1 with an empty marsupium) and 1 adult male.

Most amphipods were found in spicule 'fur' or on the surface of the sponges, and the majority were juveniles (R. Palerud pers.commn).

Two specimens of Caridion gordoni and one Munida sarsi were found in oscular cavities in $S$. ponderosus. The remaining decapods were found on the surface of the sponges.

A number of the listed crustaceans have previously been reported associated with sponges in the North Atlantic (Appendix 1) (HANSEN 1916; MONOD 1926; ARNDT 1933; Peattie \& Hoare 1981; Vader 1984a, b; KOUKOURAS \& al. 1985).

S i pu n cula. Sipunculans were found in spicule 'fur' on the sponges. Nephasoma cf. minutum constitutes a species complex. At present it is not possible to identify specimens belonging to this complex any further (A. Nørrevang pers.commn). Nephasoma abyssorum was more common on T. levis than on $T$. valdiviae, while the opposite is true of Nephasoma diaphanes which might indicate a habitat division of these two species.

B ryozoa. Bryozoans were not found on G. barretti, although about 150 specimens of this species were examined. Bryozoans were generally found attached to the surface of sponges. Exceptions are Sertella beaniana and Idmidronea atlantica found detached in the spicule 'fur' of G. macandrewii, I. atlantica, Notoplites harmeri, Porelloides laevis, and Tessaradoma boreale found detached between folds of Phakellia robusta, and Bicrisia abyssicola, Caberea ellisii and S. beaniana found detached on top of a $P$. ventilabrum. Only Bicellarina alderi was attached directly to P. rugosa. Other species were attached to a small piece of shell embedded in the tissues.
Following HaYwaRD \& RyLAND $(1979,1985)$, RYLAND \& HaYwaRD (1977) and RYland (1963) the bryozoans may be divided into two categories, encrusting and upright species. Of the 31 represented taxa, $20(64.5 \%)$ are upright and $11(35.5 \%)$ are encrusting. The most common species, Bicellarina alderi, present on nine of the sponge species (Appendix 1), is upright.

B r a c h i o p o d a. Brachiopods were only rarely found; the few specimens present were all attached with the pedicle to the sponge surface. This type of association, brachiopods attached to sponges, seems to be rare in the North Atlantic, while the opposite association, sponges growing on brachiopods, is often seen (pers. obs. and $\mathrm{O}$. Tendal pers.commn). Terebratulina retusa has previously been reported from sponges in the North Atlantic (BRUNTON \& CURRY 1979).

Ophiuroidea. Most specimens of Gorgonocephalus were found in oscular- or other cavities in Stryphnus ponderosus. One specimen was on top of an irregular Geodia barretti, and two specimens were sitting on fan-shaped $P$. robusta and $P$. ventilabrum with a number of arm tips wrapped around the rim of the fan.

Ophiopholis aculeata is the most numerous ophiuroid followed by Ophiacantha abyssicola, Amphipholis squamata, and Ophiactis abyssicola (Appendix 1). A distinct distribution pattern was observed regarding the location of the ophiuroids on S. ponderosus, Thenea levis and $T$. valdiviae (Table 5). Apart from one Ophiura cf. sarsi present in an incurrent furrow in $T$. levis, the ophiuroids were all found in spicule 'fur' of the Thenea species.

The remaining ophiuroids were found in oscular cavities in G. barretti, in spicule 'fur' on G. macandrewii, and lying on the cortex of Geodia sp.. Ophiopholis aculeata was likewise lying on the cortex of Isops phlegraei, while A. squamata was found in spicule 'fur'. A relatively large number of species, but only few individuals of each species, were found associated with $P$. rugosa (Appendix 1). They were all sitting on top of the sponges, some of them inside meshes in latticeformed specimens, or with the arms wrapped around the 'stalk' of the sponges. The ophiuroids on P. robusta, $P$. ventilabrum and Tragosia infundibuliformis were

Table 5. The location of the four most dominant ophiuroid species associated with Stryphnus ponderosus, Thenea levis and T. valdiviae.

\begin{tabular}{|c|c|c|c|c|c|c|}
\hline \multirow[b]{2}{*}{ The ophiuroid species } & \multicolumn{2}{|c|}{ Stryphnus ponderosus } & \multicolumn{2}{|c|}{ Thenea levis } & \multicolumn{2}{|c|}{ Thenea valdiviae } \\
\hline & Osculae & Spicule 'fur' & Incurrent furrow & Spicule 'fur' & Incurrent furrow & Spicule 'fur' \\
\hline Ophiactis abyssicola & $15(79 \%)$ & $4(21 \%)$ & - & - & - & - \\
\hline Ophiopholis aculeata & $12(32 \%)$ & $25(68 \%)$ & $18(90 \%)$ & $2(10 \%)$ & $16(53 \%)$ & $14(47 \%)$ \\
\hline Amphipholis squamata & - & - & $6(55 \%)$ & $5(45 \%)$ & $5(33 \%)$ & $10(67 \%)$ \\
\hline Ophiacantha abyssicola & 0 & $19(100 \%)$ & 0 & $7(100 \%)$ & $3(50 \%)$ & $3(50 \%)$ \\
\hline
\end{tabular}


either lying on the surface of the sponges or between small folds.

A marked distribution pattern of the age classes of the ophiuroids associated with $S$. ponderosus, Thenea levis and T. valdiviae was found. This applies especially to Ophiopholis aculeata:

Ophiopholis aculeata All species of ophiuroids

S. ponderosus 1 juvenile ( $3 \%$ ) 3 juveniles ( $3 \%)$

T. levis $\quad 15$ juveniles $(75 \%)$

17 juveniles (43\%)

T. valdiviae

24 juveniles $(80 \%)$

27 juveniles $(53 \%)$

Two of the ophiuroids, Amphipholis squamata and Ophiactis abyssicola, have previously been reported in association with sponges in the North Atlantic (ZAVODNIK 1976; Tyler 1980; Peattie \& Hoare 1981; Koukouras \& al. 1985).

Pterobranchia. The colonies of Rhabdopleura normani were on both Thenea species found in the spicule 'fur'. The species has previously been reported associated with sponges in Norway (Burdon-Jones 1954).

A s cidi a cea. All ascidians, except three specimens present in the 'fur' of a $G$. macandrewii, were attached to the sponge surface. Colonies of Didemnum sp. covered large parts of the surface of some specimens of $S$. ponderosus, one Styela atlantica was attached to the 'stalk' of a fan-shaped $P$. ventilabrum. A single Polycarpa pomaria was sitting in the bottom of a $9 \mathrm{~cm}$ deep oscular cavity in Stryphnus ponderosus, and another specimen was attached to the upper rim of the incurrent furrow of a $T$. levis.

One specimen of Molgula mira (MONNIOT \& KLITGAARD 1994) was found as an epibiont of Styela atlantica, which again was sitting in the spicule 'fur' of Stryphnus ponderosus. The specimen showed an anatomic adaptation for incubation of the larvae hitherto unknown in ascidians.

The occurrence of ascidians differs between the two Thenea species (Tables 2 and 3). In this way the largest number of species and the largest percentage occurrence of ascidians were found on T. levis.

A large number of the solitary ascidians are juveniles (C. Monniot pers.commn). This includes one Ascidia sp. (on T. levis), all specimens identified as Styelidae, one Polycarpa sp. (on $T$. valdiviae) and three specimens of Polycarpa pomaria (two on $S$. ponderosus and one on $T$. levis). The specimens of Ascidia tritonis (on S. ponderosus) and Styela atlantica (on I. phlegraei, Stryphnus ponderosus, $T$. levis, and Phakellia ventilabrum) are adults but small (C. Monniot pers.commn). The size of $A$. tritonis and Styela atlantica may reach 17 and $4 \mathrm{~cm}$ respectively, while the maxi- mum size of the sponge-associated specimens is 3.5 and $1.6 \mathrm{~cm}$ respectively.

Thus the most common ascidian taxa, Ascidia tritonis, Polycarpa pomaria, Styela atlantica and Styelidae, are predominantly represented by juveniles or small adults. Four of the species, Ascidia tritonis, Styela atlantica, Polycarpa pomaria, and Pyura tesselata, have previously been found associated with sponges in the North Atlantic (Appendix 1) (LÜTZEN 1967).

The occurrence of epi- and infauna

Epifauna was represented by 225 taxa, and infauna by 17 taxa. All specimens of Haplosyllis spongicola were present as infauna in Phakellia robusta and Tragosia infundibuliformis, a few specimens being found as epifauna on Stryphnus ponderosus and the two Thenea species. Gnathia abyssorum was as frequently present as infauna in Tragosia infundibuliformis and $P$. robusta as as epifauna on $S$. ponderosus. Although most frequently present as epifauna, the following twelve taxa might occur also as infauna in the axinellids: Enoplus sp., Synonchus sp., Phanoderma sp. B, Enoplolaimus sp., Pionosyllis sp., Syllis armillaris, Polynoidae indet., Lumbrineridae indet., Exogone cf. naidina, Glycera lapidum, Munna boecki, and Metopa cf. robusta.

Infauna was exclusively found in the axinellids. The infauna was most frequent and most abundant in Phakellia robusta and T. infundibuliformis. An explanation may be that these two species have larger, more distinct canals and softer structure than P. rugosa and $P$. ventilabrum.

The total absence of infauna in choristids is remarkable because a number of endobiotic species, especially polychaetes but also bivalves and echinoderms, have been recorded for Geodia cydonium (JAMESON, 1811) in the Mediterranean (SANTUCCI 1922; VIDAL 1967; ConneS \& al. 1971; ZAVODNIK 1976; KoukOuras \& al. 1985). As the structure of the Faroese species is similar to that of G. cydonium (a dominating spicule skeleton and a cortex of sterrasters), the explanation might be the existence in the Faroese species of a chemical defence. Compounds of a kind that could serve this function have, however, not been found in G. barretti, G. macandrewii, Geodia sp., l. phlegraei and Stryphnus ponderosus (HovgaARD 1991).

\section{DISCUSSION}

\section{The collection methods}

Although towing time was kept short, varying degrees of abrasion and fragmentation of the samples were inevitable because of the gravelly bottoms around the Faroes. This explains the, often poor, condition of speci- 
mens of Phakellia rugosa and $P$. ventilabrum, and the varying amounts of spicule 'fur' left on the cortex of Geodia macandrewii.

Wearing is evidently also the explanation for the often poor condition of the non-encrusting Porifera, Hydrozoa and upright Bryozoa on the sponges, and probably leads to underrepresentation of Protozoa and Bivalvia. More robust groups like Anthozoa, Cirripedia, Brachiopoda and Ascidiacea seem rather unaffected by the sampling methods.

Except for Hanleya nagelfar, the errant fauna may be influenced in two different ways during sampling. The errant fauna may be underrepresented (Appendix 1) owing to losses during towing, washing out of the sample during recovery and to escape reactions of groups such as Amphipoda and Decapoda. Thus, only one specimen of Munida sarsi was found in an oscular cavity of $S$. ponderosus, whereas galatheids repeatedly have been seen sitting on or in the vicinity of specimens of this sponge on underwater photographs. On the other hand, contamination with foreign fauna may also be expected during the sampling, either from one sponge to another or by covering of the sponges with sediment. This applies especially to sponges with a spicule 'fur'.

\section{The sponges as food}

Only one proven sponge predator, Hanleya nagelfar, was found in this investigation. The apparent scarcity of sponge predators may be a result of the sponge texture and/or the applied sampling methods. To graze the very solid choristids special adaptations are needed, such as a powerful radula and the ability of manipulating the spicules and transporting them safely through the alimentary canal as demonstrated by Hanleya nagelfar (WARÉN \& KLITGAARD 1991).

Haplosyllis spongicola has previously been reported as a predator of Mycale sp. (Fauchald \& Jumars 1979), but whether it predates on $P$. robusta has yet to be determined. Even though the axinellids have a softer texture, a predator like Haplosyllis spongicola must be expected to show adaptations to ensure a safe transport of the spicules through the alimentary canal. Another strategy is to be small enough to avoid the spicules when consuming the sponge tissue, as in Branchiosyllis oculata (Ehlers, 1887) (Polychaeta) (PAwLIK 1983), or perhaps to sort out the spicules.

Within the Crustacea, Paramphithoe hystrix (Ross, 1835) (Amphipoda) is reported as a micropredator of sponges at Bonne Bay, Newfoundland (Oshel \& SteEle 1985 ). In addition, VADER (1984a) found the species on sponges in northern Norway. RuTZLER (1976) identified five species of sponge-feeding crustaceans at the coast of Tunisia. Parasitic copepods on sponges have been reported many times from different parts of the North Atlantic (ARNDT 1933; SILÉN 1963; STOCK 1970; LAUCKNER 1980).

Nudibranchs have often been found to feed on sponges in the North Atlantic area (M' ${ }^{\prime}$ intosh 1863; Abeloos \& Abeloos 1932; ForRest 1953; Miller 1961; SWENNEN 1961; Thompson 1964; Carefoot 1967; Bloom 1976; Barbour 1979; Eyster \& Stancyk 1981; Just \& Tendal 1983; Cattaneo-Vietti 1986), while there are few reports of other gastropod orders (QuinN 1981; HARASEWYCH \& al. 1988; WARÉN \& KLITGAARD 1991).

In this investigation prosobranchs were represented by only three specimens of Magarites sp., and no nudibranchs and only few crustaceans were found. These groups are probably underrepresented owing to the sampling method. Parasitic copepods are probably uninfluenced by the sampling methods, but they are not easily found owing to their small size and often peculiar, vermiform shape. A closer examination of the canals of the sponges might demonstrate the presence of this group in the area.1

\section{The sponges as a habitat}

BARTHEL (1992) suggests that hexactinnelids play an important role in the eastern Weddell Sea, Antarctica, by colonizing areas of open sediment and modifying the sediment by deposition of spicules, thereby providing a suitable substratum for a variety of demosponge species as well as other benthic animals. That hexactinnelids in the Weddell Sea are inhabited by a large number of organisms has been demonstrated by Kunzmann (1992). Likewise, BetT \& Rice (1992) discuss the possible relationships in the Porcupine Seabight, (NE Atlantic), between hexactinellids (Pheronema carpenteri (TномsоN, 1869)), their spicule mats, and the macrobenthos. Three categories of socalled direct effect of interactions are emphasized:

1. Provision of hard substratum in an open sediment situation.

2. Provision of refugia from predation or physical hazard. 3. Provison of an enhanced food supply.

These three categories of direct effect of interactions may also apply to demosponges in the Faroese area.

Concerning the first category, sponges may on soft bottoms provide a hard substratum of sedentary groups, as exemplified by the two Thenea species. Taxa such as Hydrozoa, Bryozoa, Brachiopoda, Pterobranchia and Ascidiacea and bivalves (e.g. Modiolus phaseolinus and Hiatella arctica) may, on a soft bottom with scarcity of suitable substratum, colonize the two Thenea species (Table 3 and Appendix 1). In contrast to BETT \& RICE (1992), who found large, solitary, gelatinous ascidians 
in areas with large quantities of spicules, the majority of the ascidians found on the two Thenea species are juveniles or small adults. In addition, sponges may increase the dispersal of errant hard bottom fauna into otherwise inaccessible areas. In this way the majority of the nematodes present on the two Thenea species belong to the order Enoplida, of which most species are known to live on hard bottoms (P. Jensen pers.commn). They may on soft bottoms use sponges as a hard substratum. The same is probably true for Bathydrilus rarisetis (Oligochaeta), a species commonly found in coarse sediments (C. Erséus pers.commn). Also ophiuroids may use sponges as a substitute on soft bottoms (ZAVODNIK 1976). In the present investigation ophiuroids were found on $47-59 \%$ of the specimens of the two Thenea species (Table 3).

The second category of BETT \& RICE (1992) is the protection from large predators for organisms inhabiting the prostalia of living hexactinellids, spicule mats or sediment rich in spicules. This may also apply to the taxa found in spicule 'fur' on sponges in the present investigation. About half of the ophiuroids present on the two Thenea species are juveniles, probably because they get more and more exposed to predation when they grow. Another possible explanation, however, is that the ophiuroids change habitat when getting larger.

Likewise, cavities in the sponges may afford protection to other organisms. Ophiuroids in the incurrent furrows of T. levis and T. valdiviae and the oscular cavities of $S$. ponderosus may be protected from predation, a relationship suggested also for Ophiothrix lineata Lyman, 1860 (HeNdeER 1984) and Ophiactis savignyi (Müller \& Troschel, 1842) (Mladenov \& Emson 1988). This may also apply to crustaceans. In this way one Munida sarsi was found in an oscular cavity in $S$. ponderosus, and on underwater photographs galatheids are often seen sitting close to or on specimens of $S$. ponderosus. Similar associations between species of Munida and sponges have been reported by HARTNOLL \& al. (1992) and VILLAMizAR \& LAUGHLin (1991). Flabelliferan isopods have often been found in cavities and canals in sponges in the North Atlantic (ARNDT 1933; Pearse 1932; Dounas \& Koukouras 1986; Stone \& HEARD 1989). At the Faroe Islands both adults and juveniles of $A$. ventrosa were found in oscular cavities in $S$. ponderosus. In addition, Gnathia abyssorum was frequently present in the canals of Tragosia infundibuliformis as well as in the spicule 'fur' of $S$. ponderosus, and sponges have often been reported as a habitat of the Gnathiidae (KLITGAARD 1991).

Concerning the third category sponges might supply an associated fauna with an enhanced food supply. The food might consist of sediment and organic detritus accumulated on the sponges. This has been pointed out as an explanation several times when a more abundant occurrence of associates is observed on sponges with a complex gross morphological structure than on sponges with a simple surface contour (DAUER 1973; FRITH 1976; WENDT \& al. 1985). From underwater photographs from the Faroe Islands it appears that specimens of $S$. ponderosus can be partly covered by sediment. The presence of detritus on top of specimens of Geodia has likewise been observed on underwater photographs from the Swedish west coast (O. Tendal pers.commn). These observations, as well as the presumed accumulation of organic detritus on specimens of Thenea levis and $T$. valdiviae, could explain the occurrence of the largest number of associated taxa as well as the largest frequency of groups like Nematoda, Polychaeta and Sipuncula on these sponge species. An observation that may support this assumption is that the majority of the associated nematodes of $G$. macandrewii, as well as about half the number of those associated with $S$. ponderosus and the two Thenea species, are microbial feeders (P. Jensen pers.commn).

It has often been suggested that sponge associates utilize plankton and organic particles concentrated in the water flowing through the incurrent and excurrent canals of the sponges (ANGER 1972; WEST 1976; ZAVODNIK 1976; Westinga \& Hoetjes 1981; Bongers 1983; Costello \& Myers 1987). However, as the excurrent water has no planktonic particles owing to the filtration of the sponge, and a reduced oxygen level caused by the respiration as well as an addition of egested material, associated suspension feeders might be expected only on the incurrent surface of the sponge or inside the incurrent canals. Thus in the present investigation all specimens of Heteranomia squamula, Verruca stroemia and Terebratulina retusa were attached to the incurrent area of I. phlegraei; specimens of Modiolus phaseolinus were frequently attached to the upper rim of the incurrent furrow of Thenea levis and T. valdiviae; colonies of Didemnum sp. and incrusting sponges often covered large parts of the incurrent surface of $S$. ponderosus (similar associations are reported by RÜTZLER (1970)); Cibicides refulgens, a suspension feeder (T. Cedhagen pers.commn), was frequently attached to the incurrent surface of the geodiids.

Concerning the associated ophiuroids, Amphipholis squamata is known as an omnivore (BOFFI 1972; EMSON \& WhITFIELD 1989) and Ophiopholis aculeata as a suspension feeder (LABARBERA 1978). O. aculeata however, is also capable of eating detritus ( $R$. Emson pers.commn). It is conceivable that the individuals of these two species have advantage of the position in the incurrent furrow of $T$. levis and $T$. valdiviae by either filtering the current flow into the sponge or by collecting the particles accumulated on the poral sieves. 
The present Faroese investigation demonstrated the representation of a large number of associated species mainly present as epifauna. I suggest, that most species present as epi- or infauna in sponges in temperate/cold waters are facultative inhabitants representing the fauna present in the local geographical area. This is in contrast to warm tropical waters where a large number of apparently obligate sponge associates have been recorded (see A.J. BruCE 1976, 1977, 1981, 1983a, b). The same has been postulated for the fauna associated with the scleractinian coral Lophelia pertusa (JENSEN \& FREDERIKSEN 1992). However, to demonstrate the degree of association between the represented species and the sponges investigations of the composition of the fauna in the ambient habitat is necessary.

The results of the present investigation show that the presence of a 'fur' of spicules or of cavities like the oscular cavities of $S$. ponderosus and the incurrent furrows of T. levis and T. valdiviae are of importance for the presence of associated fauna. The importance of sponge morphology on the composition of the associated fauna is a conclusion too in FrITH (1976), Koukouras $\&$ al. (1985) and WendT \& al. (1985). Thus the morphology of the sponges as well as the possible influence of secondary metabolites from sponges can be expected to be determining factors in the composition of an associated fauna in temperate to cold waters as well as in warm tropical waters.

\section{ACKNOWLEDGEMENTS}

The investigation was done under the supervision of O.S. Tendal. I thank the Steering Committee for BIOFAR for giving me the opportunity to participate in several BIOFAR cruises during 198890 , as well as supporting my visit to the Marine Biological Laboratory in Kaldbak (the Faroe Islands) several times.

The crew of respectively the Norwegian R/V Håkon Mosby (University of Bergen), the Faroese R/V Magnus Heinason (Fiskirannsóknarstovan, Torshavn) and the Faroese coastguard vessels Tjaldrid and Olavur Helgi are acknowledged for their excellent help onboard.

For help with identification I thank T. Cedhagen, Århus (Foraminiferida); B. Christiansen, Oslo (Hydrozoa); P. Jensen, Helsingør (Nematoda); P. Garwood, Newcastle upon Tyne (Polychaeta); G. Helgason, Reykjavik (Polychaeta); T. Holthe, Trondheim (Polychaeta); P. Knight-Jones, Swansea (Polychaeta); J. D. Kudenov, Anchorage (Polychaeta); F. Pleijel, Stockholm (Polychaeta); C. Støp-Bowitz, Osio (Polychaeta); C. Erséus, Stockholm (Oligochaeta); A. Warén, Stockholm (Polyplacophora, Bivalvia); F. Krapp, Bonn (Pycnogonida); H.G. Müller, Giessen (Isopoda); J. Svavarsson, Reykjavik (Isopoda); R. Palerud, Tromsø (Amphipoda); W. Vader, Tromsø (Amphipoda); L. Sandberg, Stockholm (Decapoda); A. Nørrevang, 'Torshavn (Sipuncula); P. Tyler, Southampton (Ophiuroidea); P.N. Dilly, London (Pterobranchia); C. Monniot, Paris (Ascidiacea); from the Zoological Museum Copenhagen; O.S. Tendal (Porifera); K.W. Petersen (Hydrozoa); M.S. Thorsen (Hydrozoa); D. Eibye-
Jacobsen (Polychaeta); J. Kirkegaard (Polychaeta); M.E. Petersen (Polychaeta); J. Knudsen (Gastropoda, Bivalvia); G. Høpner Petersen (Cirripedia); E.I. Rømer (Tanaidacea, Decapoda); K.B. Hansen (Bryozoa); C. Nielsen (Brachiopoda).

I thank Roland Emson, King's College London for personal communication.

Paul Tyler, University of Southampton and Niel L. Bruce and Tom Schiфtte, Zoological Museum Copenhagen kindly commented on the manuscript and revised the English.

The investigation was supported by the Nordic Council of Marine Biology; Zoological Travel- and Excursionfund, Danish Society of Natural History; Professor Johannes Smith, D.Sc.'s trust for marine science and The Japetus Steenstrup fund.

\section{REFERENCES}

Abeloos, M. \& R. Abeloos 1932. Sur les pigments hépatiques de Doris tuberculata Cuv. (Mollusque Nudibranche) et leurs relations avec les pigments de l'eponge Halichondria panicea (Pall.). - Société de Biologie 1:1238-1240.

Allman, G.J. 1874. On the structure and systematic position of Stephanoscyphus mirabilis, the type of a new order of Hydrozoa. - Transactions of the Linnean Society of London, Second Series, Zoology 1:61-66.

Alós, C., A. Campoy \& F. Pereira 1982. Contribución al estudio de los anélidos poliquetos endobiontes de esponjas. - Acta II Simposium Ibér. Estudios Bentos Marinos 3:139-157.

Anger, K. 1972. Dipurena spongicola sp.n. (Hydrozoa, Corynidae), ein in Schwämmen lebender Hydroidpolyp aus dem Kattegat und der nördlichen Kieler Bucht. - Kieler Meeresforschungen 28:80-83.

Arndt, W. 1933. Die biologischen Beziehungen zwischen Schwämmen und Krebsen. - Mitteilungen aus dem Zoologischen Museum in Berlin 19:221-305.

Arndt, W. \& F. Pax 1936. Das zusammenleben von Krustenanemonen und Schwämmen im Mittelmeer, mit besonderer berücksichtigung der Adria. - Thalassia 2:134.

Arndt, W. \& K. Viets 1939. Die biologischen (parasitologischen) Beziehungen zwischen Arachnoideen und Spongien. Zeitschrift für Parasitenkunde 10:67-93.

Bacescu, M. 1968. Heteromysini nouveaux des eaux cubaines: trois espèces nouvelles de Heteromysis et Heteromysoides spongicola n.g. n.sp. - Revue Roumaine de Biologie. Série de Zoologie 13:221-237.

- 1971. Les Spongiaires; un des plus intéressants biotopes benthiques marins. - Rapport et proces-verbaux des reunions Commission internationale pour l'exploration scientifique de la mer Méditerranee Monaco 20:239-241. 1980. Contribution à la connaissance des Monokonophora (Crustacea, Tanaidacea) de la mer Méditerranée; description de deux espèces nouvelles, Apseudes sicilianus sp.n. et A. misarai sp.n. - Revue Roumaine de Biologie, Série de Biologie Animale 25:83-91.

Barbour, M.A. 1979. A note on the distribution and food preference of Cadlina laevis (Nudibranchia: Chromodoridae). - The Nautilus 93:61-62.

Barthel, D. 1992. Do hexactinellids structure antarctic sponge associations ? - Ophelia 36:111-118.

Bergquist, P.R. 1978. Sponges. - Hutchinson of London. 268 pp. 
Bett, B.J. \& A.L. Rice 1992. The influence of hexactinellid sponge (Pheronema carpenteri) spicules on the patchy distribution of macrobenthos in the Porcupine Seabight (bathyal NE Atlantic). - Ophelia 36:217-226.

Biernbaum, C.K. 1981. Seasonal changes in the amphipod fauna of Microciona prolifera (Ellis and Solander) (Porifera: Demospongiae) and associated sponges in a shallow saltmarsh creek. - Estuaries 4:85-96.

Bloom, S.A. 1976. Morphological correlations between dorid nudibranch predators and sponge prey. - Veliger 18:289301.

Boffi, E. 1972. Ecological aspects of ophiuroids from the phytal of S.W. Atlantic Ocean warm waters. - Marine Biology 15:316-328.

Bongers, T. 1983. Bionomics and reproductive cycle of the nematode Leptosomatum bacillatum living in the sponge Halichondria panicea. - Netherlands Journal of Sea Research 17:39-46.

Bouillon, J. 1965. Diagnoses préliminaires de trois hydroides de Roscoff. - P. 54 in: L'Inventaire de la Faune Marine de Roscoff (Cnidaires - Cténaires).

- 1971. Sur quelques hydroides de Roscoff. - Cahiers de Biologie Marine 12:323-364.

Brattegard, T. 1980. Platymysis facilis gen. et sp. nov. (Crustacea: Mysidacea:Heteromysini) from the Saba Bank, Caribbean Sea. - Sarsia 65:49-52.

Brinkhurst, R.O. 1982. British and other marine and estuarine oligochaetes. - Synopses of the British Fauna 21:1-127.

Bruce, A.J. 1976. Discias mvitae sp. nov, a new sponge associate from Kenya (Decapoda Natantia, Disciadidae). Crustaceana 31:119-130.

- 1977. Notes on some Indo-Pacific Pontoniinae, XXIX. Epipontonia spongicola gen. nov., sp. nov., from Wasin Island, Kenya. - Crustaceana 32:304-315.

- 1981. Onycocaridella prima, new genus, new species, a new pontoniine sponge- associate from the Capricorn Islands, Australia (Decapoda, Caridea, Pontoniinae). - Journal of Crustacean Biology 1:241-250.

- 1983a. Epipontonia anceps n. sp., a sponge-associated pontoniine shrimp from Heron Island, Queensland. (Crustacea: Decapoda: Palaemonidae). - Records of the Australian Museum 35:19-28.

- 1983b. Expédition Rumphius II (1975) crustacés parasites, commensaux, etc. (Th. Monod éd.). IX. Crustacés décapodes (lere partie: Natantia Pontoniinae). - Bulletin du Muséum National d'Histoire Naturelle, Paris (A) 5:871-902.

Brunton, C.H.C. \& G.B. Curry 1979. British brachiopods. - Synopses of the British Fauna 17:1-64.

Burdon-Jones, C. 1954. The habitat and distribution of Rhabdopleura normani Allman. - Universitetef i Bergen Årbok 1954. Naturvitenskapelig rekke 11:1-17.

Calder, D.R. 1970. Hydroid and young medusa stages of Dipurena strangulata (Hydrozoa, Corynidae). - Biological Bulletin 138:109-114.

Carefoot, T. 1967. Growth and nutrition of three species of opisthobranch molluses. --Comparative Biochemistry and Physiology 21:627-652.

Carlgren, O. 1945. Polypdyr. III. Koraldyr. - Danmarks Fauna $51: 1-167$.
Cattaneo-Vietti, R. 1986. On pleurobranchomorpha from italian seas (Mollusca: Ophisthobranchia). - The Veliger 28:302309.

Cedhagen, T. (1994). Taxonomy and biology of Hyrrokkin sarcophaga gen. et sp. n., a parasitic foraminiferan (Rosalinidae). - Sarsia 79:65-82.

Connes, R., J. Paris \& J. Sube 1971. Réactions tissulaires de quelques démosponges vis-à-vis de leurs commensaux et parasites. - Le Naturaliste Canadien 98:923-935.

Costello, M.J. \& A.A. Myers 1987. Amphipod fauna of the sponges Halichondria panicea and Hymeniacidon perleve in Lough Hyne, Ireland. - Marine Ecology Progress Series 41:115-121.

Dauer, D.M. 1973. Polychaete fauna associated with Gulf of Mexico sponges. - Florida Scientist 36:192-195.

Dounas, C. \& Ath. Koukouras 1986. The genus Cymodoce Leach (Isopoda, Flabellifera) in the North Aegean Sea. Crustaceana 51:306-308.

Duffy, J.E. 1992. Host use patterns and demography in a guild of tropical sponge-dwelling shrimps. - Marine Ecology Progress Series 90:127-138.

Emson, R.H. \& P.J. Whitefield 1989. Aspects of the life history of a tide pool population of Amphipholis squamata (Ophiuroidea) from South Devon. - Journal of the $\mathrm{Ma}$ rine Biological Association of the United Kingdom 69:27-41.

Enckell, P.H. 1980. Fältfauna/kräftdjur. - Signum i Lund, Sverige. $680 \mathrm{pp}$.

Erdman, R.B. \& N.J. Blake 1987. Population dynamics of the sponge-dwelling alpheid Synalpheus longicarpus, with observations on $S$. brooksi and S. pectiniger, in shallowwater assemblages of the eastern Gulf of Mexico.-Journal of Crustacean Biology 7:328-337.

Eyster, L.S. \& S.E. Stancyk 1981. Reproduction, growth and trophic interactions of Doriopsilla pharpa Marcus in South Carolina. - Bulletin of Marine Science 31:72-82.

Fage, L. 1928. Remarques sur le comportement du Tritaeta gibbosa (Bate), crustace amphipode, commensal des éponges. - Bulletin de la Société Zoologique de France 53:285-291.

Fauchald, K. \& P.A. Jumars 1979. The diet of worms: a study of polychaete feeding guilds. - Oceanography and Marine Biology: an Annual Review 17:193-284.

Fauvel, P. 1923. Polychétes errantes. - Faune de France 5:1488.

Forester, A.J. 1979. The association between the sponge Halichondria panicea (Pallas) and scallop Chlamys varia (L.): a commensal-protective mutualism. - Journal of Experimental Marine Biology and Ecology 36:1-10.

Forrest, J.E. 1953. On the feeding habits and the morphology and mode of functioning of the alimentary canal in some littoral dorid nudibranchiate Mollusca. - Proceedings of the Linnean Society of London 164:225-235.

Frith, D.W. 1976. Animals associated with sponges at North Hayling, Hampshire. -Zoological Joumal of the Linnean Society 58:353-362. 
- 1977. A preliminary analysis of the associations of amphipods Microdeutopus damnoniensis (Bate), $M$. anomalus (Rathke) and Corophium sextoni Crawford with sponges Halichondria panicea (Pallas) and Hymeniacidon perleve (Montagu). - Crustaceana 32:113-118.

George, J.D. \& G. Hartmann-Schröder 1985. Polychaetes: british Amphinomida, Spintherida and Eunicida. - Synopses of the British Fauna 32:1-221.

Gibbs, P.E. \& E.B. Cutler 1987. A classification of the phylum Sipuncula. - Bulletin of the British Museum (Natural History). Zoology. London 52:43-58.

Hansen, H.J. 1916. Crustacea Malacostraca III. Isopoda. - Danish Ingolf-Expedition 3:1-262.

Harasewych, M.G., S.A. Pomponi \& T.M. Askew 1988. Spongivory in pleuroto-mariid gastropods. - Nautilus 102:92-98.

Hartnoll, R.G., A.L. Rice \& M.J. Attrill 1992. Aspects of the biology of the galatheid genus Munida (Crustacea, Decapoda) from the Porcupine Seabight, Northeast Atlantic. - Sarsia 76:231-247.

Hayward, P.J. \& J.S. Ryland 1979. British ascophoran bryozoans. - Synopses of the British Fauna 14:1-312.

- 1985. Cyclostome bryozoans. - Synopses of the British Fauna 34:1-147.

Heard, R.W. \& D.G. Perlmutter 1977. Description of Colomastix janiceae n.sp., a commensal amphipod (Gammaridea: Colomastigidae) from the Florida Keys, USA. - Proceedings of the Biological Society of Washington 90:30-42.

Helgason. G.V., A. Gardarsson, J. Svavarsson, K. Adalsteinsdottir \& H. Gudmundsson 1990. Polychaetes new to the icelandic fauna, with remarks on some previously recorded species. - Sarsia 75:203-212.

Hendler, G. 1984. The association of Ophiothrix lineata and Callyspongia vaginalis: a brittlestar-sponge cleaning symbiosis?-Marine Ecology 5:9-27.

Høisæter, T. 1986. An annotated checklist of marine molluscs of the norwegian coast and adjacent waters. -Sarsia 71:73145.

- 1990. An annotated checklist of the echinoderms of the norwegian coast and adjacent waters. - Sarsia 75:83-106.

Hougaard, L. 1991. Indholdsstoffer fra marine organismer Licentiatafhandling Kemisk Laboratorium II, Københavns Universitet. $108 \mathrm{pp}$.

Jensen, A. \& R. Frederiksen 1992. The fauna associated with the bank-forming deepwater coral Lophelia pertusa (Scleractinaria) on the faroe shelf.-Sarsia 77:53-69.

Just, H. \& O.S. Tendal 1983. On the sponge-diet of Archidoris pseudargus (Rapp, 1827). - Veliger 25:403-404.

King, P.E. 1974. British sea spiders. - Synopses of the Brttish Fauna 5:1-68.

Klitgaard, A.B. 1991. Gnathia abyssorum (G.O. Sars, 1872) (Crustacea, Isopoda) associated with sponges. - Sarsia 73:33-39

Koukouras, Ath., E. Voultsiadou-Koukoura, H. Chintiroglou \& C. Dounas 1985. Benthic bionomy of the North Aegean Sea. III. A comparison of the macrobenthic animal assemblages associated with seven sponge species. - Cahiers de Biologie Marine 26:301-319.
Koukouras, A., A. Russo, E. Voultsiadou-Koukoura, C. Dounas \& C. Chintiroglou 1992. Relationship of sponge macrofauna with the morphology of their hosts in the North Aegean Sea. - International Revue der gesamten Hydrobiologie und Hydrographie 77:609-619.

Kramp, P.L. 1935. Polypdyr I. (Coelenterata) ferskvandspolypper og goblepolypper - Danmarks Fauna 41:1-207.

Kunzmann, K. 1992. Die mit ausgewählten Schwämmen (Hexactinellida und Demospongiae) aus dem Weddellmeer, Antarktis vergesellschaftete Fauna. - Dissertation zur Erlangung des Doktorgrades der Mathematisch-Naturwissenschaftlichen Fakultät der Christian-Albrechts-Universität zu Kiel. 108 pp.

LaBarbera, M. 1978. Particle capture by a Pacific brittle star: experimental test of the aerosol suspension feeding model. - Science 210:1147-1149.

Lauckner, G. 1980. Diseases of Porifera. - Pp. 139-165 in: Kinne, O. (ed.). Diseases of marine animals. Vol. I. General as. pects. Protozoa to Gastropoda. John Wiley and Sons, New York.

Lewis, S.M. 1982. Sponge-zoanthid associations: functional interactions. - Pp. 465-474 in: Rützler, K. \& I.G. Macintyre (eds). The Atlantic Barrier Reef. Ecosystem at Carrie Bow Cay, Berlize, I. Structure and communities. Smithsonian contribution marine science 12.

Loeblich, A.R. Jr. \& H. Tappan 1988. Foraminiferal genera and their classification. - Van Nostrand Reinhold company, New York. 970 pp. +847 Plates.

Lützen, J. 1967. Sækdyr. - Danmarks Fauna 75:1-267.

Lugli, A. \& S. Palazzi 1991. Cerithiopsis acuminata Hallgass, 1985, sinonimo juniore di $C$. barleei Jeffreys, 1867 . Bollettino Malacologico 27:139-140.

Lundbeck, W. 1902. Porifera. Part 1. Homorrhaphidae and Heterorrhaphidae. - Danish Ingolf Expedition 6(1):1-108.

- 1905. Porifera. Part 2. Desmacidonidae (Pars.). - Danish Ingolf Expedition 6(2):1-219.

- 1910. Porifera. Part 3. Desmacidonidae (Pars.). - Danish Ingolf Expedition 6(3):1-124.

Millar, R.H. 1970. British ascidians. - Synopses of the British Fauna 1:1-92.

Miller, M.C. 1961. Distribution and food of the nudibranchiate Mollusca of the south of the Isle of Man. - Journal of Animal Ecology 30:95-116.

M'Intosh, W.C. 1863. On the nudibranchiate Mollusca of St. Andrews; Edwardsia; and the polyps of Alcyonium digitatum. - Proceedings of the Royal Society of Edinburgh 5:387-393.

Mladenov, P.V. \& R.H. Emson 1988. Density, size structure and reproductive characteristics of fissiparous brittle stars in algae and sponges: evidence for interpopulational variation in levels of sexual and asexual reproduction. $-\mathrm{Ma}$ rine Ecology Progress Series 42:181-194.

Monniot, C. \& A.B. Klitgaard 1994. A new incubatory mode in an ascidian: redescription of Molgula mira (ÄrnbäckChristie-Linde, 1931). - Ophelia 40:159-165.

Monod, T. 1926. Les Gnathiidae. - Mémoires de la Société de Sciences Naturelles du Maroc 13:1-667.

Nørrevang, A., T. Brattegard, A.B. Josefson, J.-A. Sneli \& O. Tendal 1994. List of BIOFAR stations. - Sarsia 79:1t 180. 
Oshel, P.E. \& D.H. Steele 1985. Amphipod Paramphithoe hystrix: a micropredator on the sponge Haliclona ventilabrum.Marine Ecology Progress Series 23:307-309.

Pansini, M. 1970. Inquilinismo in Spongia officinalis, Ircinia fasciculata e Petrosia ficiformis della Riviera Ligure di Levante. - Bollettino dei Musei e degli Instituti Biologici dell'Università di Genova 38:5-17.

Pawlik, J.R. 1983. A sponge-eating worm from Bermuda. Branchiosyllis oculata (Polychaeta, Syllidae). -Marine Ecology 4:65-79.

Pearse, A.S. 1932. Inhabitants of certain sponges at Dry Tortugas. - Carnegie Institution of Washington Publication 435:117-124.

- 1947. On the occurrence of ectoconsortes on marine animals at Beaufort, N.C. - Journal of Parasitology 33:453458.

- 1950. Notes on the inhabitants of certain sponges at Bimini. - Ecology 31:149-151.

Peattie, M.E. \& R. Hoare 1981. The sublittoral ecology of the Menai Strait. II. The sponge Halichondria panicea (Pallas) and its associated fauna. - Estuarine, Coastal and Shelf Science 13:621-635.

Petersen, K.W. 1990. Evolution and taxonomy in capitate hydroids and medusae. - Zoological Journal of the Linnean Society 100:101-231.

Platt, H.M. \& R.M. Warwick 1988. Free-living marine nematods. Part II. British chromadorids. - Synopses of the British Fauna 38:1-502.

Quinn, J.F.Jr. 1981. The gastropods, Calliostoma orion Dall, 1889 (Trochidae) and Heliacus (Gyriscus) worsfoldi n.sp. (Architectonicidae), from the Bahama Islands. - The Nautilus 95:150-156.

Rees, W.J. 1939. The hydroid of the medusa Dipurena halterata (Forbes). - Journal of the Marine Biological Association of the United Kingdom 23:343-346.

Riser, N.W. 1982. Observations on some poorly known syllid polychaetes from the Gulf of Maine. - Canadian Journal of Zoology 60:105-111.

Rullier, F. 1974. Quelques annélides polychètes de Cuba recueillies dans les éponges. - Travaux du Muséum d'Histoire Naturelle 'Gr. Antipa' 14:9-77.

Russell, F.S. 1953. The medusae of the British Isles. - Cambridge University Press. $530 \mathrm{pp}$.

Ryland, J.S. 1963. Systematic and biological studies on Polyzoa (Bryozoa) from western Norway. - Sarsia 14:1-59.

Ryland, J.S. \& P.J. Hayward 1977. British anascan bryozoans. Synopses of the British Fauna 10:1-188.

Rützler, K. 1968. Loxosomella from Tedania ignis, the Caribbean Fire Sponge. - Proceeding of the United States $\mathrm{Na}$ tional Museum 124:1-11.

- 1970. Spatial competition among Porifera: solution by epizoism.-Oecologia (Berlin) 5:85-95.

- 1976. Ecology of tunesian commercial sponges. - Tethys 7:249-264.

Santucci, R. 1922. La Geodia cydonium come centro di associazione biologica. $-R$. Comitato Talassografico Italiano 103:5-19.
Scott, P.J.B., H.M. Reiswig \& B.M. Marcotte 1988. Ecology, functional morphology, behaviour, and feeding in coral- and sponge-boring species of Upogebia (Crustacea: Decapoda: Thalassinidea). - Canadian Journal of Zoology 66:483495.

Silén, L. 1963. Clionophilus vermicularis n.gen. n.sp., a copepod infecting the burrowing sponge, Cliona. - Zoologiska Bidrag frăn Uppsala 35:269-288.

Stock, J.H. 1967a. Sur trois espèces de copépodes synonymes ou confondues: Asterocheres echinicola (Norman), A. parvus Giesbrecht et A. kervillei Canu (Cyclopoida Siphonostoma): - Bulletin Zoologisch Museum Universiteit van Amsterdam 1:31-35.

- 1967b. Copépodes associés aux invertébrés des côtes du Roussillon. VI. Sur deux espèces nouvelles de la famille des Spongiocnizontidae. - Vie et Milieu, Série A: Biologie Marine 18:189-201.

- 1967c. Copépodes associés aux invertébrés des côtes du Roussillon. VII. Sur deux espèces-jumelles de Cyclopoïdes Siphonostomes: Scottocheres elongatus (T. \& A. Scott) et $S$. laubieri spec.nov. - Vie et Milieu. Série A: Biologie Marine 18:203-214.

- 1970. Apodomyzon n.gen,, a highly transformed siphonostome cyclopoid copepod, parasitic in the sponge Haliclona from Roscoff. - Beaufortia 18:141-150.

Stone, I. \& R.W. Heard 1989. Excorallana delaneyi, n.sp (Crustacea: Isopoda: Excorallanidae) from the northeastern Gulf of Mexico, with observations on adult characters and sexual dimorphism in related species of Excorallana Stebbing, 1904. - Gulf Research Reports 8:199-211.

Swennen, C. 1961. Data on distribution, reproduction and ecology of the nudibranchiate molluscs occurring in the Netherlands. - Netherlands Journal of Sea Research 1:191240.

Thompson, T.E. 1964. Grazing and the life cycles of british nudibranchs. - Pp. 275-297 in: Grisp, D.J. (ed.). Grazing in terrestrial and marine environments. British ecological society symposium no. 4. Blackwell, Oxford.

Tuzet, O. \& J. Paris 1964. Réactions tissulaires de l'éponge Subrites domuncula (Olivi) Nardo, vis-a-vis de ses commensaux et parasites. - Vie et Milieu Vol. Jubilaire d. a. Georges Petit. Supplement 17:147-155.

Tyler, P.A. 1980. Deep-sea ophiuroids. - Oceanography and Marine Biology: an Annual Review 18:125-153.

Uebelacker, J.M. 1978. A new parasitic polychaetous annelid (Arabellidae) from the Bahamas. - Journal of Parasitology 64:151-154.

- 1982. Haplosyllis agelas, a new polychaetous annelid (Syllidae) from the Bahamas. - Bulletin of Marine Science 32:856-861.

Uriz, M.-J., D. Rosell \& M. Maldonado 1992. Parasitism, commensalism or mutualism ? The case of Scyphozoa (Coronatae) and horny sponges. - Marine Ecolog. Progress Series 81:247-255

Vader, W. 1984a. Notes on norwegian marine Amphipoda. 7.Amphipod associates of Geodia sponges in western Norway. - Fauna norvegica Serie A 5:14-16.

- 1984b. Notes on norwegian marine Amphipoda. 8.Amphipods found in association with sponges and tunicates. - Fauna norvegica Serie A 5:16-21. 
Vidal, A. 1967. Étude des fonds rocheux circalittoraux le long de la cote du Roussillon. - Vie et Milieu 18:167-219.

Villamizar, E. \& R.A. Laughlin 1991. Fauna associated with the sponges Aplysina archeri and Aplysina lacunosa in a coral reef of the Archipiélago de Los Roques, National Park, Venezuela. - Pp. $522-542$ in: Reitner, J. \& H. Keupp (eds). Fossil and recent sponges. Springer-Verlag. Berlin, Heidelberg.

Voultsiadou-Koukoura, E., A. Koukouras \& A. Eleftheriou 1987. Macrofauna associated with the sponge Verongia aerophoba in the North Aegean Sea. - Estuarine, Coastal and Shelf Science 24:265-278.

Warén, A. \& A. Klitgaard 1991. Hanleya nagelfar, a spongefeeding ecotype of $H$. hanleyi or a distinct species of chiton ? - Ophelia 34:51-70.

Wendt, P.H., R.F. Van Dolah \& C.B. O'Rourke 1985. A comparative study of the invertebrate macrofauna associated with seven sponge and coral species collected from the South Atlantic Bight. - Journal of the Elisha Mitchell Scientific Society 101:187-203.
West, D.A. 1976. Aposematic coloration and mutualism in spongedwelling tropical zoanthids. - Pp. 443-452 in: Mackie, G.O. (ed.). Coelenterate ecology and behaviour. Plenum Press.

- 1979. Symbiotic zoanthids (Anthozoa: Cnidaria) of Puerto Rico. - Bulletin of Marine Science 29:253-271.

Westinga, E. \& P.C. Hoetjes 1981. The intrasponge fauna of Spheciospongia vesparia (Porifera, Demospongiae) at Curaçao and Bonaire. - Marine Biology 62:139-150.

Williams, A.B. 1987. Upogebia synagelas, new species, a commensal mud shrimp from sponges in the western central Atlantic (Decapoda: Upogebiidae). - Proceeding of the Biological Society of Washington 100:590-595.

Zavodnik, D. 1976. Adriatic echinoderms inhabiting benthic organisms. - Thalassia Jugoslavica 12:375-380.

Zullo, V.A. \& J.D. Standing 1983. Sponge-inhabiting barnacles (Cirripedia: Archaeobalanidae) of the Carolinian Province, southeastern United States, with the description of a new species of Membranobalanus Pilsbry. - Proceedings of the Biological Society of Washington 96:468-477.

Accepted 15 January 1995. 
Appendix 1 . The fauna associated with the eleven examined sponge species. The taxa are listed in phylogenetical order according to the following authors: Protozoa: (Loeblich \& Tappan 1988), Hydrozoa: (Kramp 1935), Anthozoa: (Carlgren 1945), Nematoda: (Platt \& Warwick 1988), Polychaeta: (George \& HARTMANN-SChröder 1985), Oligochaeta: (BrinkHURST 1982), Mollusca: (HøisÆTER 1986), Pycnogonida: (KING 1974), Crustacea: (ENCKell 1980), Sipuncula: (GibBs \& CuTLER 1987), Bryozoa: (RYLAND \& HaYwARD 1977; Hayward \& Ryland 1979, 1985), Brachiopoda: (Brunton \& Curry 1979), Echinodermata: (Høiseter 1990), Ascidiacea: (Millar 1970).$+=$ present but not counted, $*=$ the species has previously been reported associated with sponges in the North Atlantic, $a=$ new record for the Faroe Islands area, ${ }^{*}=$ the species was found as an epibiont of Styela atlantica (Ascidiacea). G.b. = Geodia barretti, G.m. $=$ G. macandrewii, G.sp. = Geodia sp., S.p. = Stryphnus ponderosus, T.l. = Thenea levis, T.v. =T. valdiviae, P.ro. $=$ Phakellia robusta, P.ru. $=$ P. rugosa, $P . v .=P$. ventilabrum, T.. = Tragosia infundibuliformis .

\begin{tabular}{|c|c|c|c|c|c|c|c|c|c|c|c|}
\hline & G.b. & G.m. & G.sp. & l.p. & S.p. & T.l. & T.v. & P.ro. & P.ru. & P.v. & T.i. \\
\hline \multicolumn{12}{|l|}{ PROTOZOA } \\
\hline cf. Dendrophrya erecta WRIGHT, 1861 & & & & + & & & & & & & \\
\hline a Tholosina confusa (CusHMAN, 1920) & & & & + & & & & & & & \\
\hline T. vesicularis BRADY, 1879 & & & & + & & & & & & & \\
\hline Ammodiscus cf. intermedius HöGLund, 1947 & & + & & & & & & & & & \\
\hline a Trochammina sp. & & & & + & & & & & & & \\
\hline Quinqueloculina seminulum (L., 1758) & & + & & & & & & & & & \\
\hline * Hyrrokkin sarcophaga CEDHAGEN, 1994 & + & + & + & + & & & & & & & \\
\hline $\begin{array}{l}\text { Planulina ariminensis D'ORBIGNY, } 1826 \\
\text { Cibicides lobatulus (WALKER \& JACOB, 1798) }\end{array}$ & & & & $\begin{array}{l}+ \\
+\end{array}$ & & & & & & & \\
\hline C. refulgens MONTFORD, 1808 & + & + & + & + & & & & & & & \\
\hline $\begin{array}{l}\text { Nonion umbilicatulum (MONTAGU, 1803) } \\
\text { Paromalina coronata (PARKER \& JONES, 1857) }\end{array}$ & & + & & $\begin{array}{l}+ \\
+\end{array}$ & & & & & & & \\
\hline $\begin{array}{l}\text { PORIFERA } \\
\text { a * Aplysilla sulphurea } \text { SCHULzE, } 1878^{*}\end{array}$ & & & & & + & & & & & & \\
\hline Unidentified morphological types. & & + & + & + & + & + & + & + & + & + & + \\
\hline HYDROZOA & & & & & & & & & & & \\
\hline Tubulariidae indet. & & & & & & & & + & + & + & + \\
\hline a * Hybocodon prolifer L. Agassiz, 1862 & & & & & & & & + & + & + & + \\
\hline Eudendrium rameum (PALLAS, 1766) & & & + & & & & & & & & \\
\hline Lafoeidae indet. & & & & + & & & & & & & \\
\hline Lafoea sp. & & & + & & & & & & & & \\
\hline L. gracillima (ALDER, 1856) & & + & + & + & & & & & & & \\
\hline Halecium sp. & & & & + & & & & & & & \\
\hline H. beani JoHnsTON, 1847 & & & & + & & & & & & & \\
\hline Kirchenpaueria pinnata (L., 1758) & & & + & & & & & & & & \\
\hline Halopteris catharina (JOHNSTON, 1833) & & & & + & & & & & & & \\
\hline Nemertesia antennina (L., 1758) & & & & & + & & & & & & \\
\hline Sertulariidae indet. & & & & + & & & & & & & \\
\hline Sertularella gayi (LAMOUROLx, 1821) & + & & + & + & + & & & & & & \\
\hline Unidentified morphological types. & & + & + & + & + & + & + & + & + & + & + \\
\hline ANTHOZOA & & & & & & & & & & & \\
\hline Capnella sp. & + & & & & & & & & & & \\
\hline C. glomerata (VERRILL, 1869) & & & & 1 & 38 & & & & & & \\
\hline C. florida (RATHKE, 1806) & 8 & & & & 17 & & & & & & \\
\hline NEMERTEA & & & & & & & & & & & \\
\hline Nemertea indet. & & 1 & & & 2 & 1 & & & & & \\
\hline NEMATODA & & & & & & & & & & & \\
\hline Enoplus sp. & & 46 & & 6 & 116 & 42 & 47 & & & 1 & \\
\hline a * E. cf. communis BastIAN, 1865 & & & & & & 3 & 2 & & & & \\
\hline q Enoploides sp. & & & & & 1 & & & & & & \\
\hline Enoplolaimus sp. & & 1 & & & & 2 & 1 & & 1 & & \\
\hline Crenopharynx sp. A & & & & & 20 & 1 & & & & & \\
\hline C. sp. B & & & & & 1 & & & & & & \\
\hline Micoletzkya sp. & & & & & 1 & & 2 & & & & \\
\hline Phanoderma sp. A & & & & & 4 & 9 & 5 & & & & \\
\hline$P . \mathrm{sp} . \mathrm{B}$ & & & & & & 2 & 7 & & & 1 & \\
\hline
\end{tabular}




\begin{tabular}{|c|c|c|c|c|c|c|c|c|c|c|c|c|}
\hline & & G.b. & G.m. & G.sp. & I.p. & S.p. & T.l. & T.v. & P.ro. & P.ru. & P.v. & T.i. \\
\hline \multirow[t]{4}{*}{$a$} & Anticoma sp. & & & & & 4 & 3 & 1 & & & & \\
\hline & Leptosomatidae sp. A & & & & & 1 & & & & & & \\
\hline & Leptosomatidae sp. B & & & & & & 5 & 1 & & & & \\
\hline & Leptosomatidae sp. C & & & & & & & & & 1 & & \\
\hline \multirow[t]{2}{*}{ a } & Cylicolaimus sp. & & & & & & 8 & & & & & \\
\hline & Leptosomatum sp. & & 2 & & & 18 & 9 & 6 & & & & \\
\hline \multirow[t]{2}{*}{$a$} & Platycomopsis sp. & & & & & 1 & & & & & & \\
\hline & Synonchus sp. & & 172 & & 9 & 33 & 170 & 187 & 2 & 3 & 1 & \\
\hline a & Thoracostoma sp. & & 12 & & & 8 & & 1 & & & & \\
\hline a & Oxystomina sp. & & 1 & & & & & & & & & \\
\hline \multirow[t]{2}{*}{ a } & Viscosia sp. & & 3 & & & 1 & & & & & & \\
\hline & Eurystomina sp. & & & & & & 1 & 1 & & & & \\
\hline a & Rhabdodemania sp. & & & & & & 1 & & & & & \\
\hline a & Sabatieria sp. & & & & & & 1 & & & & & \\
\hline \multirow[t]{2}{*}{ a } & Paracanthonchus sp. & & 1 & & & 19 & & & & & & \\
\hline & Halichoanolaimus sp. & & & & & & 1 & & & & & \\
\hline a & Desmodora sp. & & 2 & & & & & & & & & \\
\hline a & Theristus sp. & & & & & 3 & & & & & & \\
\hline \multicolumn{13}{|c|}{ POLYCHAETA } \\
\hline & Polynoidae indet. & & + & + & & + & + & + & 3 & & & 1 \\
\hline \multirow[t]{2}{*}{ a } & Pholoe pallida CHAMBERs, 1985 & & & & & & & & & 1 & & \\
\hline & Sigalionidae indet. & & & & & & + & & & & & \\
\hline$a$ & Eulalia hanssoni PLEJJEL, 1987 & & & & & 1 & 1 & & & & & \\
\hline $\mathbf{a}$ & E. mustela PleIJEL, 1987 & & 1 & & & & & & & & & \\
\hline \multirow[t]{2}{*}{ a } & E. tjalfiensis DITLEVSEN, 1917 & 1 & & & & & 1 & 2 & & & & \\
\hline & Eumida sp. & & & & & & & & 1 & & & \\
\hline \multirow[t]{8}{*}{ a * } & Glycera lapidum QUATREFAGES, 1865 & & 2 & & 2 & 1 & 9 & 10 & & & & 1 \\
\hline & Goniada maculata $\emptyset_{\mathrm{RSTED}}, 1843$ & & & & & 1 & 1 & & & & & \\
\hline & G. norvegica $\emptyset \mathrm{RSTED}, 1844$ & & & & & & 1 & & & & & \\
\hline & Sphaerodorum $\mathrm{sp}$ & & & & & & & 1 & & & & \\
\hline & Nereimyra punctata (O.F. MÜLLER, 1788) & & & & & 1 & & 1 & & & & \\
\hline & Syllidae indet. & & & & & 2 & & 1 & & & & \\
\hline & Autolytinae indet. & & & & & & & & & & & 1 \\
\hline & Autolytus sp. & & 1 & & & & & & & & & \\
\hline $\mathbf{a}$ & Exogone longicirris WEBSTER \& BENEDICT, 1887 & & & & & 1 & & 1 & & & & \\
\hline \multirow{2}{*}{$a$} & E. naidina $\emptyset_{\mathrm{RSTED}}, 1845$ & & & & & 14 & 5 & 3 & & 1 & & \\
\hline & E. verugera (CLAPARÉDE, 1868) & & & & & 1 & & 2 & & & & \\
\hline a $*$ & Haplosyllis spongicola (GRUBE, 1855) & & & & & 1 & 1 & 3 & 587 & & & 1 \\
\hline a & Odontosyllis sp. & & & & & 1 & & & & & & \\
\hline \multirow[t]{3}{*}{ a } & Pionosyllis sp. & & 3 & & & 3 & & 1 & 6 & 1 & & 2 \\
\hline & Sphaerosyllis sp. & & & & & 1 & & 2 & & & & \\
\hline & S. erinaceus CLAPARÉDE, 1863 & & 6 & & & 12 & 1 & & & & & \\
\hline \multirow{2}{*}{ a } & S. hystrix CLAPARÉDE, 1863 & & 8 & & & 7 & 4 & 1 & & & & \\
\hline & Syllis armillaris (O.F. MüLLER, 1776) & 1 & 8 & 4 & 10 & 60 & 1 & 2 & 1 & & & \\
\hline$a$ & S. cornuta RATHKE, 1843 & & & & & 2 & 7 & 5 & & & & \\
\hline \multirow[t]{12}{*}{$a *$} & Trypanosyllis coeliaca CLAPARÉDE, 1868 & & 2 & 1 & 1 & 3 & 1 & 7 & & & & \\
\hline & cf. Nereidae & & & & & 1 & & & & & & \\
\hline & Nereis sp. & & & & & 1 & & & & & & \\
\hline & N. pelagica L., 1761 & 1 & 6 & 1 & 1 & 27 & 2 & 1 & 1 & & 1 & \\
\hline & N. zonata MaLMGREN, 1867 & & & & & 2 & & 1 & & & & \\
\hline & Eunicidae indet. & & + & + & + & + & + & + & & & & \\
\hline & Lumbrineridae indet. & & + & & & + & + & + & 1 & & & \\
\hline & Dorvilleidae indet. & & & & & + & + & + & & & & \\
\hline & Paraonidae indet. & & & & & + & + & + & & & & \\
\hline & Spionidae indet. & & + & & & + & + & + & & & & \\
\hline & Aphelochaeta sp. & & & & & 1 & 1 & 5 & & & & \\
\hline & Chaetozone sp. indet. & & & & & & 2 & 1 & & & & \\
\hline
\end{tabular}


C. sp. A

C. sp. B

cf. Cirratulus sp.

C. incertus McINTOSH, 1916

a Tharyx sp.

a cf. Pherusa falcata STøP-BowITZ, 1948

* Notomastus cf. latericeus M. SARS, 1851 Maldanidae indet.

cf. Asclerocheilus intermedius (SAINT-JoSEPH, 1894)

a Sclerocheilus cf. minutus GRUBE, 1863

a Oligobregma cf. aciculata HARTMAN, 1965

Oweniidae indet.

Sabellidae indet.

Brachiomma sp.

Euchone sp.

a E. southerni BANSE, 1970

Jasmineira sp.

a J. caudata LANGERHANS, 1880

a cf. J. elegans SAINT-JOSEPH, 1894

a Myxicola cf. aesthetica (ClaparÉde, 1870)

Ampharetidae indet.

Trichobranchidae indet.

Terebellidae indet.

Polycirrus sp.

Placostegus tridentatus (FABRICIUS, 1779)

\section{OLIGOCHAETA}

Tubificidae indet.

a Bathydrilus rarisetis (ERSÉUs, 1975)

a Grania pusilla ERSÉUs, 1974

MOLLUSCA, Polyplacophora

口 * Hanleya nagelfar (Lovén, 1846)

MOLLUSCA, Gastropoda

Margarites sp.

MOLLUSCA, Bivalvia

Yoldiella nana (M. SARS, 1865)

a Dacrydium ockelmanni MATTSON \& WARÉN, 1977

Modiolus phaseolinus (PHILIPPI, 1844)

Acar nodulosa (O.F. Müller, 1776)

Bathyarca pectunculoides (SCACCHI, 1834)

a Chlamys vitrea (GMELIN, 1791)

Heteranomia squamula (L., 1758)

Astarte sp.

A. sulcata (DA CostA, 1778)

* Hiatella arctica (L., 1767)

ARACHNIDA, Acariformes

Halacaridae indet.

\section{PYCNOGONIDA}

Nymphon sp.

N. grossipes FABRICIUS, 1780

N. leptocheles G.O. SARS, 1888

a N. cf. micronyx G.O. SARS, 1888

N. spinosissimum (NoRMAN, 1894)

a Callipallene producta G.O. SARS, 1888

a Pseudopallene malleolata (G.O. SARS, 1881) $\begin{array}{llllllllll}\text { G.b. G.m. G.sp. I.p. S.p. } & \text { T.I. } & \text { T.v. } & \text { P.ro. } & \text { P.ru. } & \text { P.v. } & \text { T.i. }\end{array}$

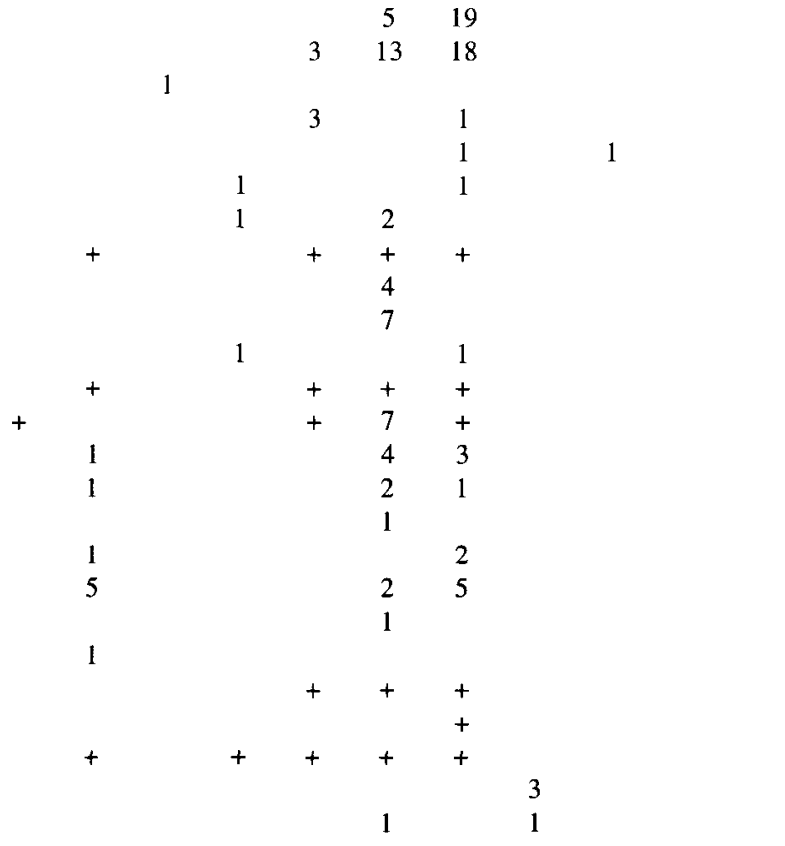

2

$\begin{array}{lllll}4 & 9 & 2 & 24 & 1\end{array}$

3

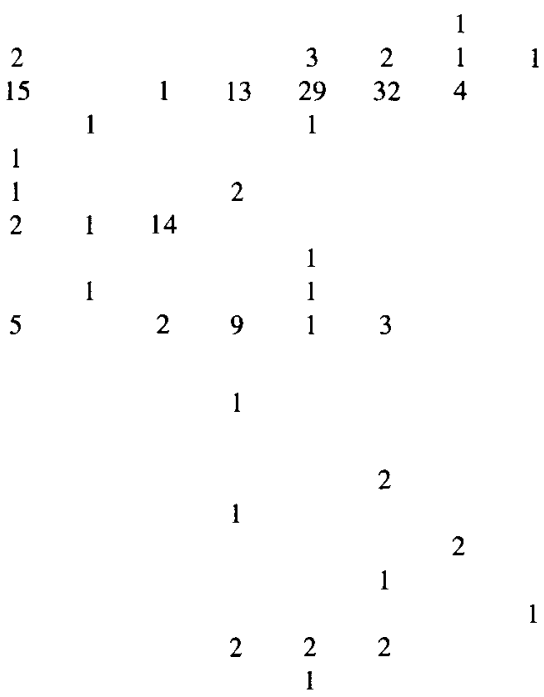




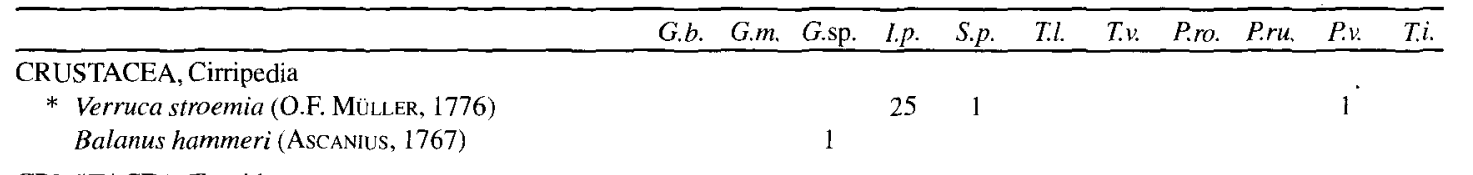

CRUSTACEA, Tanaidacea Apseudes spinosus (M. SARS, 1858)

CRUSTACEA, Isopoda Gnathia abyssorum juvenile G. abyssorum (G.O.SARS, 1872) females

* G. abyssorum (G.O.SARS, 1872) males Astacilla longicornis (SOWERBY, 1806) Aega ventrosa M. SARS, 1848

a Disconectes cf. furcatus G.O. SARS, 1870

* Munna boecki KRøYER, 1839 Nannoniscus oblongus G.O. SARS, 1869

* Janira maculosa LEACH, 1814

CRUSTACEA, Amphipoda

Aeginella spinosa BOECK, 1860

Gammaridea indet.

Lysianassidae indet.

Orchomene sp.

O. cf. serratus (BOECK, 1861)

Metopa sp.

M. cf. robusta G.O. SARS, 1892

Harpinia cf. pectinata G.O. SARS, 1891

Byblis crassicomis METZGER, 1875

Leucothoe sp.

Cressasp.

Ischyroceridae indet.

cf. Gammaropsis sp.

Pardalisca cf. tenuipes G.O. SARS, 1893

Aoridae indet.

* Laothoes meinerti BOECK, 1870

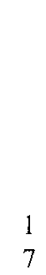

CRUSTACEA, Decapoda

a Caridion gordoni (BATE, 1858)

* Pagurus bermhardus (L., 1758)

a Munida sarsi BrinkMAN, 1936

Hyas coarctatus LEACH, 1815

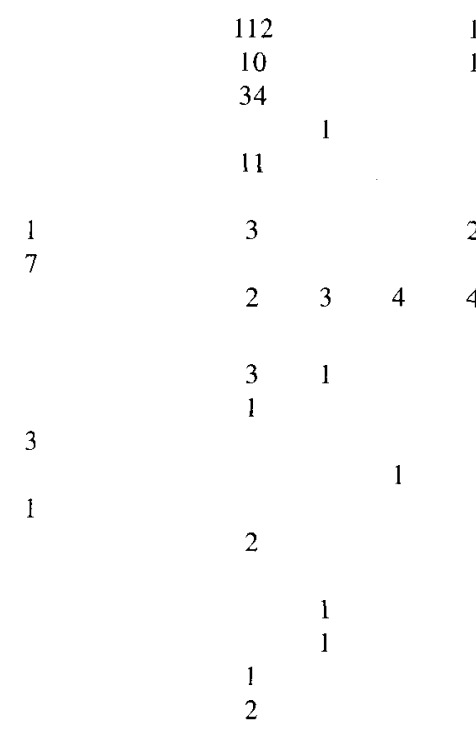

110

4

1

4

\section{1}

1

$$
1
$$

1

2

1

SIPUNCULA

a Nephasoma abyssorum Koren \& DaNIELSSEN, 1875

a N. diaphanes (GEROULD, 1913)

a N. flagriferum (SELENKA, 1885)

N. cf. minutum (KEFERSTEIN, 1862)

a Onchnesoma steenstrupi KOREN \& DANIELSSEN, 1875

BRYOZOA

Bicrisia abyssicola KLUGE, 1962

Crisia sp.

C. eburnea (L., 1758)

Tubulipora sp.

a cf. T. penicilliata (FABricLUS, 1780)

Idmidronea sp.

I. atlantica (FORBES, in JOHNSTON, 1847)

Plagioecia patina (LAMARCK, 1816)

Diplosolen obelia (JOHNSTON, 1838)

a Tervia sp.

Annectocyma major (JOHNSTON, 1847) 
Entalophoroecia cf. deflexa (Couch, 1842)

Hornea lichenoides (L., 1758)

Disporella hispida (FLEMING, 1828)

Chartella barleei (BUSK, 1860)

Amphiblestrum sp.

A. flemingii (Busk, 1854)

A. minax (Busk, 1860)

a Cellaria fistulosa L., 1758

Caberea ellisii (FLEMING, 1814)

a Notoplites jeffreysii Norman, 1868

N. harmeri RYLAND, 1963

Bicellarina alderi (BusK, 1859)

Smittoidea reticulata (J. MACGILlivray, 1842)

Porella compressa (SOWERBY, 1805)

Porelloides laevis (FLEMING, 1828)

P. struma (Norman, 1868B)

Palmicellariasp.

a Tessaradoma boreale (Busk, 1860)

Sertella beaniana (KING, 1846)

a S. rara (JULLIEN, 1903)

BRACHIOPODA

* Terebratulina retusa $(\mathrm{L} ., 1758)$

Glaciarcula spitzbergensis (DAVIDSON, 1852)

$\begin{array}{llllllllll}\text { G.b. G.m. G.sp. I.p. S.p. T.l. } & \text { T.v. } & \text { P.ro. } & \text { P.ru. } & \text { P.v. } & \text { T.i. }\end{array}$

ECHINODERMATA, Ophiuroidea

a Ophioscolex purpureus DÜBEN \& Koren, 1846

q Gorgonocephalus caputmedusae (L., 1758)

a G. lamarckii (MülLER \& TrOSCHEL, 1842)

Ophiactis sp.

* O. abyssicola (M. SARS, 1861)

O. balli (THOMPSON, 1840)

Ophiopholis aculeata (L., 1767)

* Amphipholis squamata (Delle ChIAJE, 1829)

Ophiacantha sp.

O. abyssicola G.O. SARS, 1871

a O. anomala G.O. SARs, 1871

a O. bidentata (RETzIUs, 1805)

a O. spectabilis G.O. SARS, 1871

a O. granulifera VerriLl, 1885 a

a. Ophiocten gracilis (G.O. SARS, 1871)

Ophiura sp.

O. sarsii LüTKEN, 1858

\section{PTEROBRANCHIA}

* Rhabdopleura normani ALLMAN, 1869

\section{ASCIDIACEA}

a Polycitoridae indet.

Didemnum sp.

Ascidia sp.

* A. tritonis Herdman, 1883

Styelidae indet.

a * Styela atlantica (VAN NAME, 1912)

a S. similis Monniot, C., 1970

Polycarpa sp.

* P.pomaria (S Avigny, 1816)

a P.porculus Monniot \& Monniot, 1979

* Pyura tesselata (Forbes, 1848)

Q ** Molgula mira (

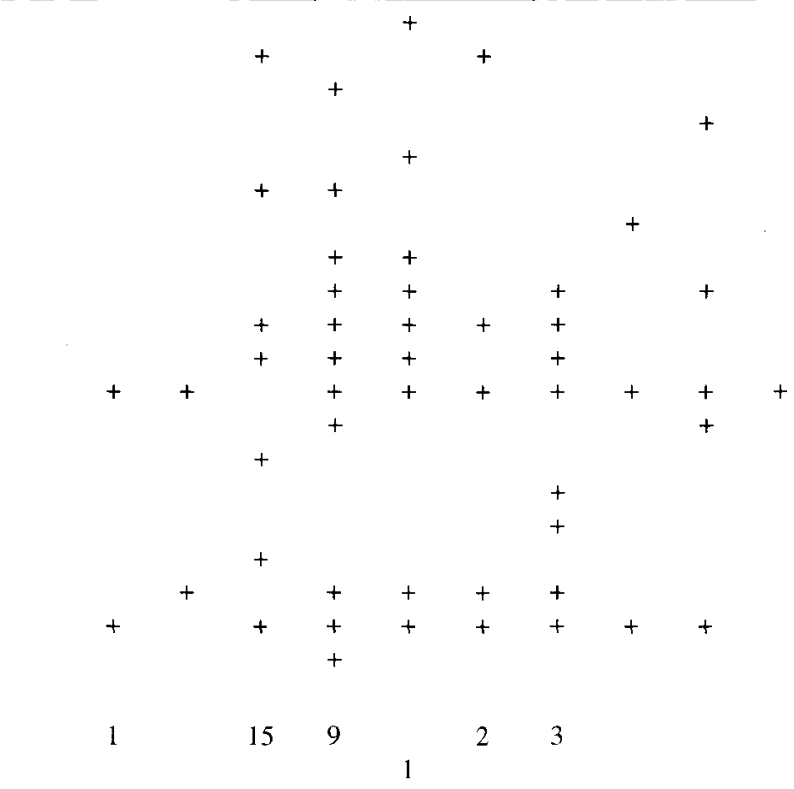


Appendix 2. For each of the eleven sponge species is given a list of the BIOFAR stations at which specimens examined for associated fauna were collected. Data of each station (position, depth, gear, temperature, sediment) in NørREvaNG \& al. (1994).

\begin{tabular}{ll}
\hline Sponge species & BIOFAR Stns \\
\hline Geodia barretti & $043,117,156,163,234,268,279,287,352,376,469,474,476,483,486,488,504,530$, \\
Geodia macandrewii & $531,534,535,536,540,550,551,559,756$ \\
& $117,287,328,375,376,379,451,453,469,476,486,488,504,535,540,550,559,734$, \\
Geodia sp. & 756 \\
& $043,279,328,373,374,379,474,475,476,486,498,530,531,532,535,536,551,558$, \\
Isops phlegraei & 559 \\
& $043,279,282,287,375,451,453,469,474,476,483,486,488,530,536,550,551,558$, \\
Stryphnus ponderosus & 559,734 \\
& $043,046,148,282,374,375,389,451,453,469,470,474,475,476,486,488,503,504$, \\
Thenea levis & $535,536,540,558,559,756$ \\
Thenea valdiviae & $047,156,158,376,377,378,451,453,483,486,487,550,559$ \\
Phakellia robusta & $156,158,282,375,376,377,378,451,453,469,483,486,550,559$ \\
& $019,052,149,153,156,190,234,281,282,346,356,373,374,375,379,389,451,453$, \\
Phakellia rugosa & $468,471,475,476,530,550,552,558,559$ \\
Phakellia ventilabrum & $027,122,156,175,264,279,281,377$ \\
& $019,043,118,153,155,279,347,374,377,451,453,468,471,474,475,476,483,488$, \\
Tragosia infundibuliformis & $530,536,551,552,558,559$ \\
& $043,052,149,150,156,191,205,279,281,346,356,375,451,452,453,468,471,474$, \\
& $476,483,537$
\end{tabular}

